\title{
Optimization of US-Electropersulfate Process for Leachate Treatment by Response Surface Methodology
}

\author{
Majid Kermani ${ }^{1}$, Samira Ahmadi ${ }^{2}$, Zahra Shahbazi ${ }^{2}$, Roghayeh Bahadori', \\ Zhila Ghavami $^{4}$, Jamal Mehralipour ${ }^{* 5}$ \\ 1. Associate Professor of Environmental Health Engineering Department, School of Public Health, \\ Iran University of Medical Science, Tehran, Iran \\ 2. Graduated of Environmental Health Engineering. Faculty of Public Health, Hamadan University of \\ Medical Science, Hamadan, Iran \\ 3. MSc Students of Environmental Health Engineering. Faculty of Public Health, Tehran University of \\ Medical Science, Tehran, Iran \\ 4. MSc students of Environmental Health Engineering. Research Committee (SRC), Faculty of Public Health, Hamadan \\ University of Medical Sciences, Hamadan, Iran \\ 5. Ph.D Candidate of Environmental Health Engineering, Iran University of Medical Sciences, Tehran, Iran \\ *E-mail: jamalmehralipour@yahoo.com
}

Received: 14 Oct 2018 ; Accepted: 4 Jan 2019

\begin{abstract}
Background and Objectives: Chemical Oxidation Demand (COD) is an important parameter in treatment of leachate. Leachate from solid waste has high pollutants that must be treated before discharge to environment. The aim of this study was optimization of US-Electro/persulfate process, predicate of optimum conditions by RSM for landfill leachate treatment.

Methods: In this experimental study, a sonochemical reactor with one liter volume that equipped with $40 \mathrm{KHz}$ and two Iron electrodes as an anode and two Copper electrodes as a cathode that connected to direct current supply source was used. In the final step of study, $\mathrm{pH}(2-4), \mathrm{S}_{2} \mathrm{O}_{8}{ }^{2-}$ (1-2 $\mathrm{g} / \mathrm{L})$, direct electrical current (1.5-3 A) and reaction time parameters as an independent parameters were studied. In optimum condition, corrosion of the electrodes in anode and energy consumption were measured. Sludge properties before and after the process were analyzed by SEM/EDAX and FT-IR spectroscopy.

Results: By using this software (design Expert), the optimum condition was done at $\mathrm{PH}=3.41, \mathrm{~S}_{2} \mathrm{O}_{8}{ }^{2-}$ dose $=1.2 \mathrm{~g} / \mathrm{L}$, current density $=2.41 \mathrm{~A}$, and reaction time were $70 \mathrm{~min}$. In this condition the efficiency of COD removal was $75 \%$. The R-squared and Adj R-squared process was 0.78 and 0.88 respectively. The electrodes corrosion in optimum condition were $0.77 \mathrm{~g}$ and energy consumption was $9.23 \mathrm{~kW} / \mathrm{kg}$ COD. The results of analysis indicate that changes in sludge during the process has happened and elements structure in leachate has observed, the most obvious oxygen and iron increased in sludge after the process.

Conclusion: The US-Electro/persulfate has a good efficiency in COD removal and with this model can be tested with a few run and high accuracy to optimize the process.
\end{abstract}

Keywords: Optimization, US-EPS, Leachate treatment, Landfill, Response surface methodology. 


\title{
بهينهسازى فرايند سونوالكترويرسولفات براى تصفيه شيرابه لندفيل با استفاده از مدل سطح یاسخ
}

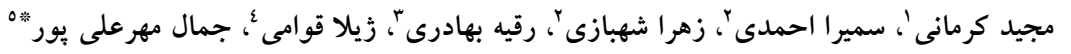 \\ ' دانشيار گروه مهندسى بهداشت محيط، دانشكده بهداشت دانشكاه علوم يزشكى ايران

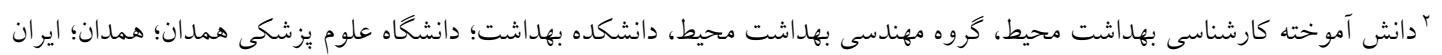

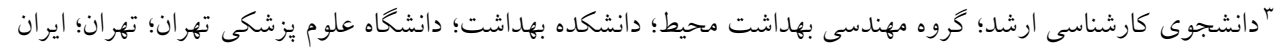

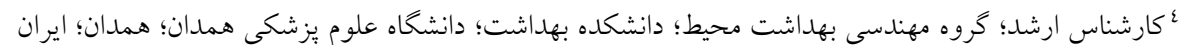 \\ • دانشجوى دكترى تخصصى(Ph.D) مهندسى بهداشت محيط، گروه مهندسى بهداشت محيط؛ دانشكده بهداشت؛ دانشگاه علوم يزشكى ايران؛ تهران؛ ايران.

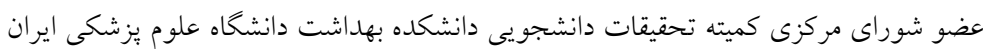

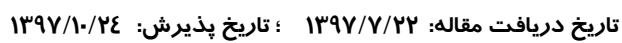

\section{קكند}

مقدمه: COD بعنوان يكى از يارامترهاى مهم تصفيه مطرح مىباشد. شيرابه يُماند داراى آلـودگى بسـيار بـالايى اسـت كـه بايستى

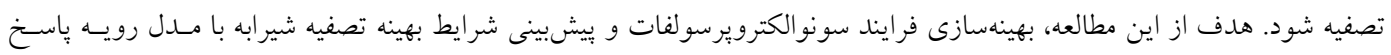

40KHz روش بر رسى: در اين مطالعه، از يك محفظه واكنش سونوشيمايى با حجم يك ليتر مجهز به امواج اولتراسونيك با فركانس

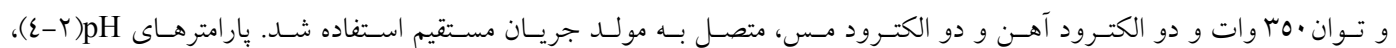

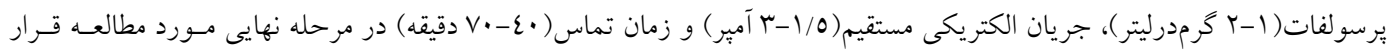

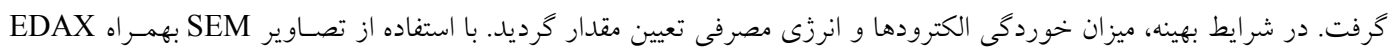
و خصوصيات لجن قبل و بعد فرايند بررسى شد. FT-IR

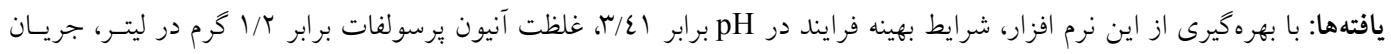

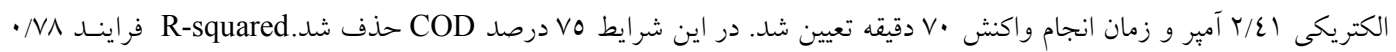

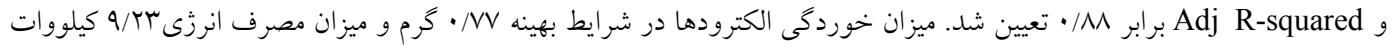

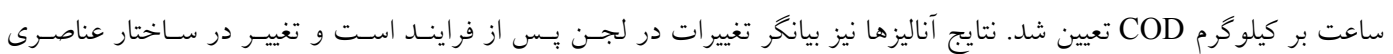

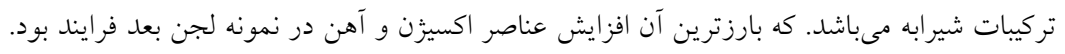

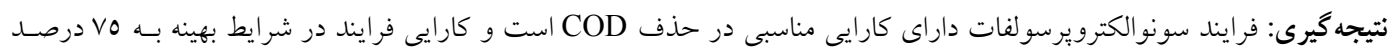

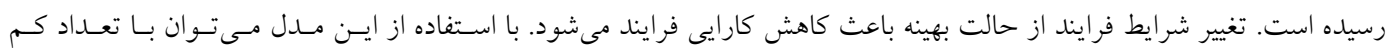
آزمايش، هزينه بايينتر و دقت بالا فرايند را بهينهسازى نمود.

كلمات كليدى: فرايند سونو الكترويرسولفات، تصفيه شيرابه، محل دفن، روش سطح پياسخ 
بصورت الكتريكى هيدروزن ير اكسايد توليد نمـود و متعاقـب

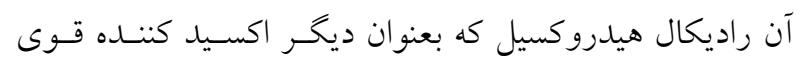

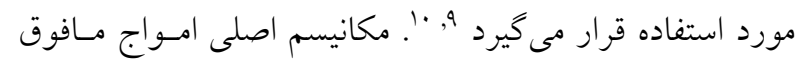

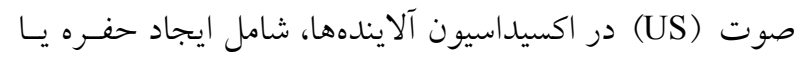

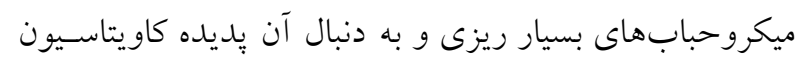

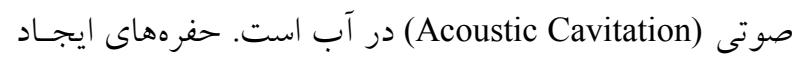

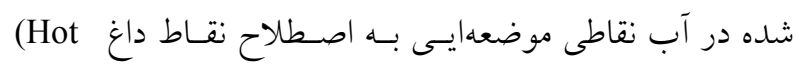
Spot) است، كه در نهايـت منجـر بـه تشـكيل راديكـالهـاى و و $\mathrm{H}^{\bullet} \mathrm{OH}^{\bullet}$ امواج US در فرايند فوق داراى اثر تشديد كنندكى مسىباشـد. امواج US در بخشى از فرايند باعث كمى به فعالسازى آنيون

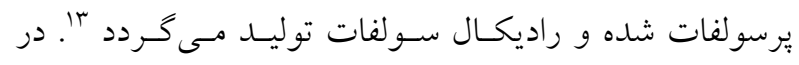

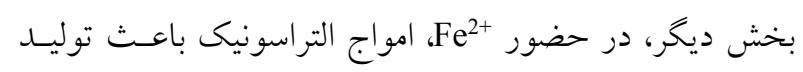

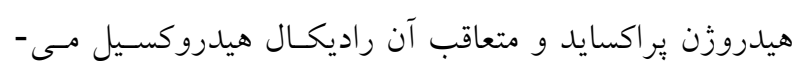

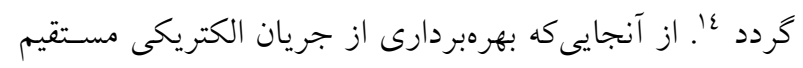

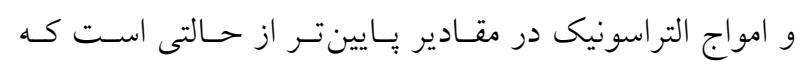

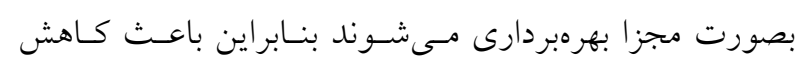

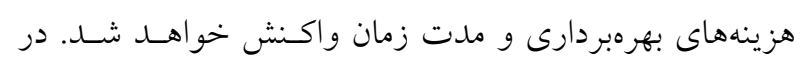

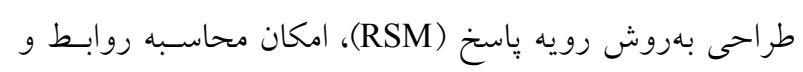

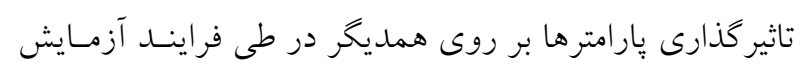

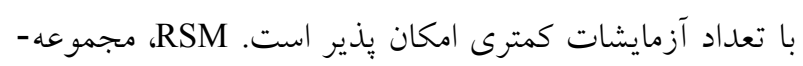

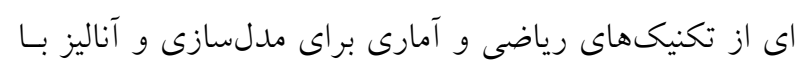

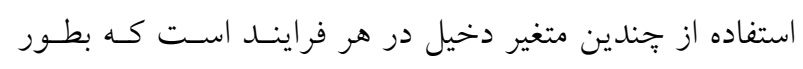
سودمندى باعث مشخص شدن تاثير يارامترهاى موثر بر فرايند

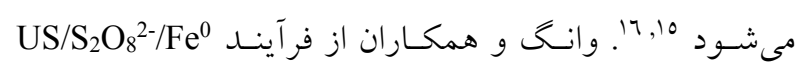

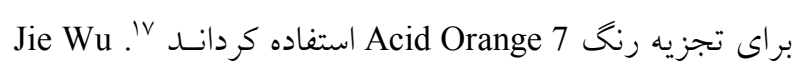

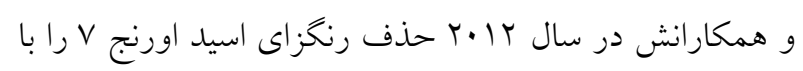

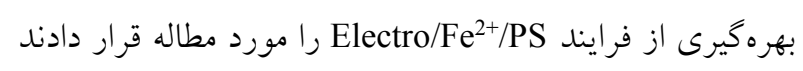

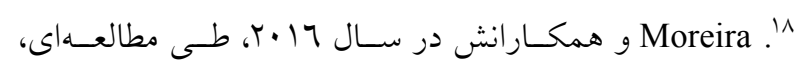

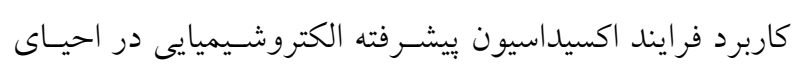

\section{مقدهه}

شيرابه حاصل از يسماند، باعث ايجاد آلودگى بسيار بالايى

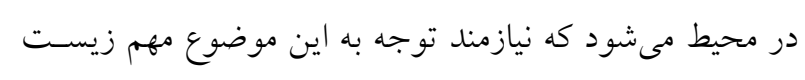
محيطى است. ماهيت، نوع تركيبات، نوع روش دفـن يسـماند،

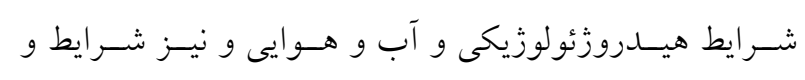
خصوصيات داخلى لندفيل از مهمترين عوامل موثر بر كميت و

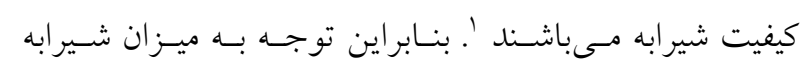

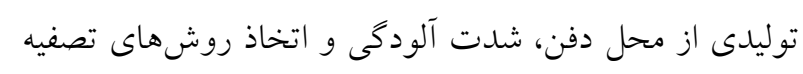
و كاهش بار آلـودگى شـيرابه از نظـر بهداشـت محسيط امسرى

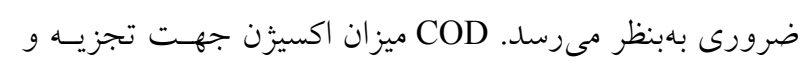

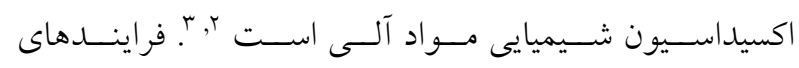
اكسيداسيون بيوسته (AOPs) بر پيايه توليد راديكالهاى اكسيد الهيد

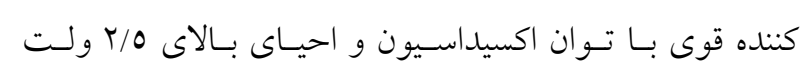

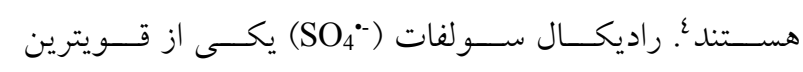

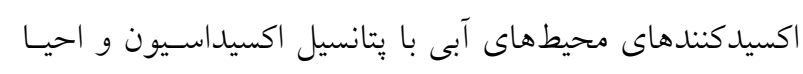

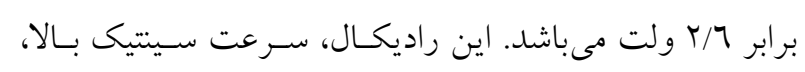
يايدارى بيشتر و وابستكى كمتر به رباينــدهــاى راديكـال دارد

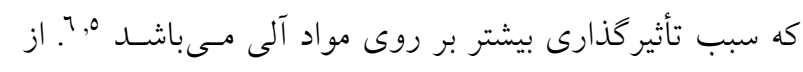

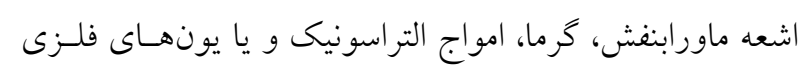

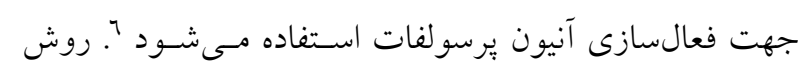

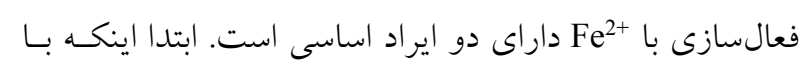

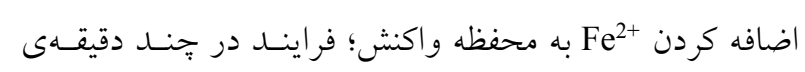
ابتدايى داراى كارايى خواهد بود و در ادامه با تبـديل تسـه

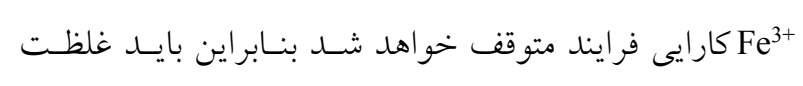
بالايى از Fe به محيط اضافه نمود كه با اين اقدام باعث توليد

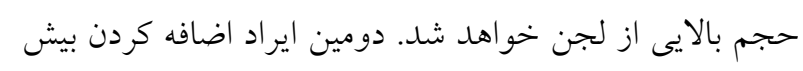

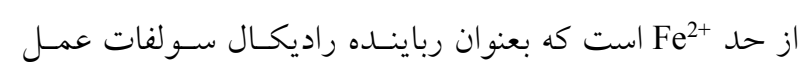

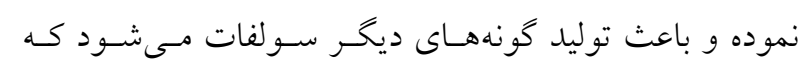

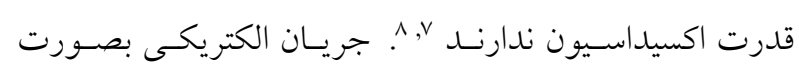

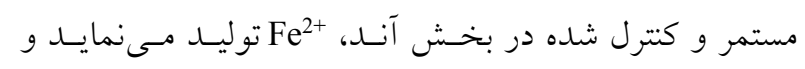

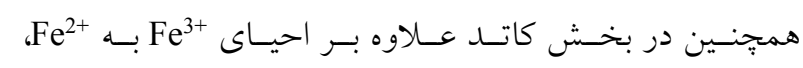


تنظيم pH اوليه از pH متـر ديجيتـالى مـــ Sensoal سـاخت شـركت HACH آلمــان اسـتفاده شـــ ميـزان COD مطــابق دستور العملC. 5220 ذكر شده در مرجع روشهاى اسـتاندارد آزمايشات آب و فاضلاب اندازهيرى شد با. در اين مطالعه از طراحى تركيبى مركزى(CCD) با استفاده از نرم افزار ل Design)

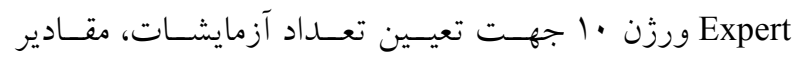

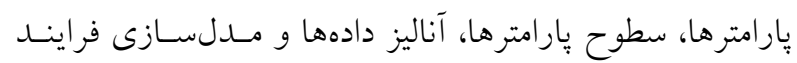

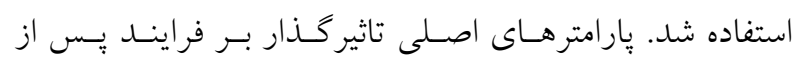

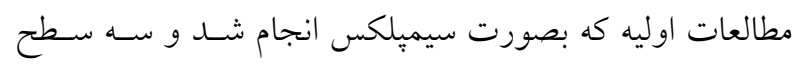
تعيين شد شامل pH اوليه محيط در محسـدودهى (ع-Y)، ميـزان جريان الكتريكى ورودى بـه محفظـه واكـش (1/0-ب آميـر)،

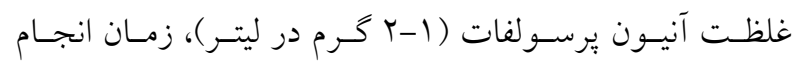
واكنش(•ع-•V دقيقه) در حضور امواج US مورد بررسى قرار كرفت. در اين مطالعه ·ب نمونه توسط اين نرم افـزار طراحسى

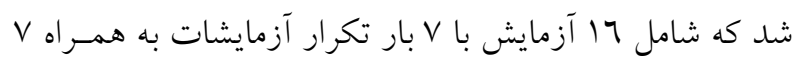

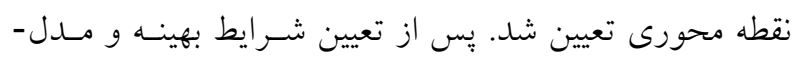

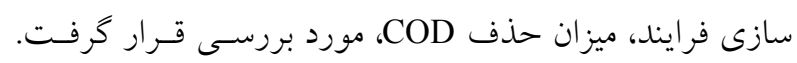
تصوير شماتيك و واقعى از راكتور مورد استفاده در مطالعه در شكل ارايه شده است.
شيرابه به بررسى متغيرهاى عمليـاتى تيرداختنـــ 19. توضيحات ارايه شده و لزوم تصفيه شيرابه با بار آلودگى بسيار بالا، هدف از اين مطالعه، بهينهسازى فرايند(US-EPS)، تعيسين

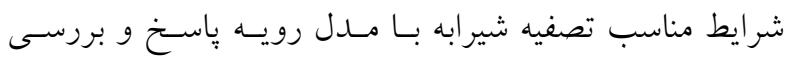
تغييرات لجن بود.

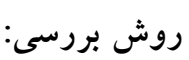

در اين مطالعه، از شيرابه واقعى در طـى مراحـل مختلـف رك

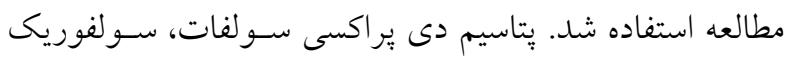
اسيد، سديم هيدروكسيد، ويـال COD سـاخت شـركتهـاى مرك و سيخما - آلدريج خريدارى شد. در اين يزوهش، يـى واحد جـايلوت شـامل يـكى محفظهـ سونوشـيميايى بـا جريـان

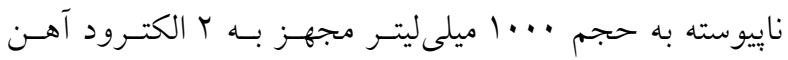
(بعنوان آند) و r الكترود مس (بعنوان كاتد) با مسـاحت فعـال

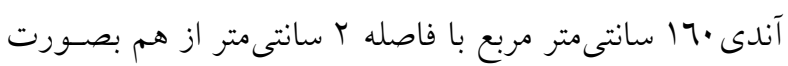

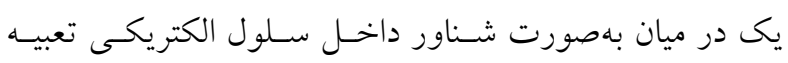
شدند، مورد استفاده قرار گرفت. ارتباط الكترودها بـا دسـتخاه توليد جريان مستقيم الكتريكى مدل P405 S سـاخت شـركت بDAK امواج US با توانايى ايجاد فركانس و قدرت بـه ترتيـب KHz

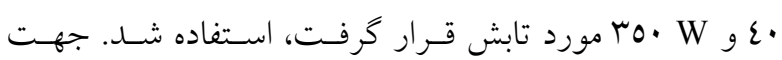

جدول ا: يار امترهاى مورد استفاده در طراحى به همراه مقادير و محدودهى در نظر كرفته شده

\begin{tabular}{ccccccc}
\hline & & & & \\
\hline \\
\hline
\end{tabular}



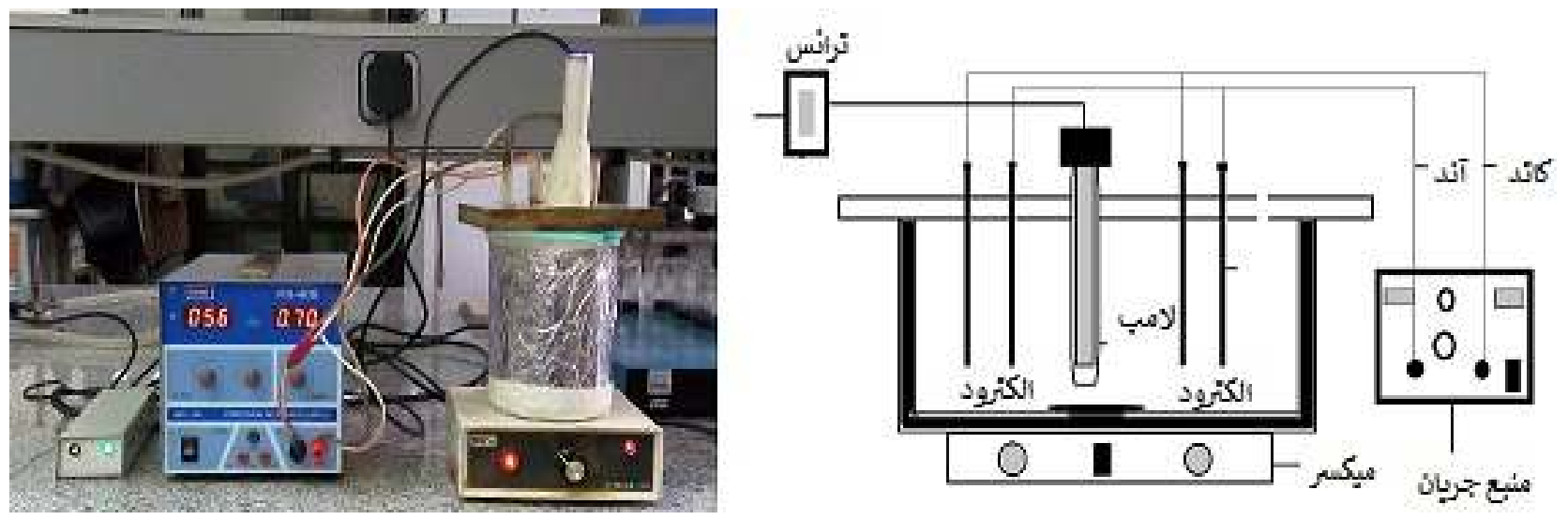

شكل ا: تصوير شماتيك و واقعى راكتور مورد استفاده

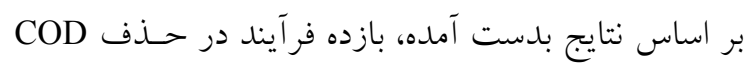

يافتهها

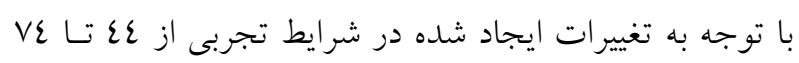
ويزگ ئىهاى شيرابه

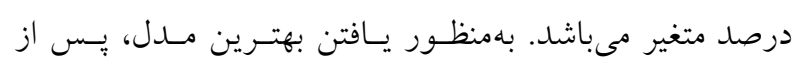

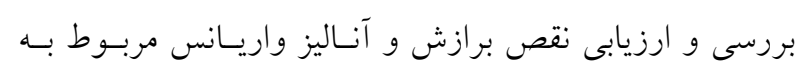

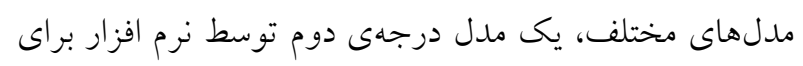

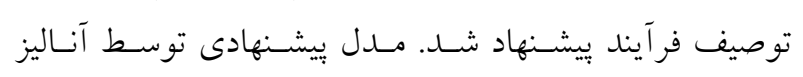

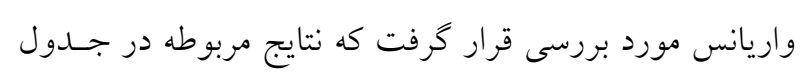

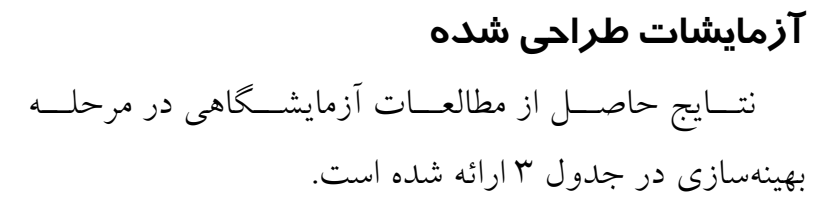
ع نشان داده شده است. در ابتداى مطالعه، مشخصات فيزيكسى و شـيميايى شـير ابه

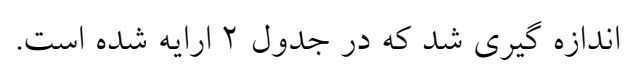
(n)

جدول r: مشخصات فيزيكى و شيميايى شيرابه

\begin{tabular}{|c|c|c|c|c|}
\hline $01 \cdot 0$. & 7) & $\mathrm{mg} / \mathrm{L}$ & COD & 1 \\
\hline rAVA. & $r \cdot V \Lambda \cdot-r T V \Lambda \cdot$ & $\mathrm{mg} / \mathrm{L}$ & BOD5 & r \\
\hline ro/q & $r-r \cdot / \Lambda$ & $\mathrm{mg} / \mathrm{L}$ & فسفر & r \\
\hline $0 V / 0$ & $V \cdot-\varepsilon 0$ & $\mathrm{mg} / \mathrm{L}$ & يتاسيم & $\varepsilon$ \\
\hline TV/ro & $V N / V-07$ & $\mathrm{mg} / \mathrm{L}$ & نيترات & 。 \\
\hline תr/r & $\cdot / \mu 1-\cdot / 10$ & $\mathrm{mg} / \mathrm{L}$ & DO & 7 \\
\hline $7 / 90$ & $V / I-7 / \Lambda$ & - & $\mathrm{pH}$ & $v$ \\
\hline or & $09-\varepsilon 0$ & $\mathrm{Ms} / \mathrm{cm}$ & EC & $\wedge$ \\
\hline
\end{tabular}


مجيد كرمانى و همكاران

جدول سا: آزمايشات طراحى شده با روش CCD و نتايج حاصل از آن

\begin{tabular}{|c|c|c|c|c|c|c|}
\hline مراحل آزمايش & $\mathrm{pH}$ & غِارامترها & $\begin{array}{c}\text { جريان الكتريكى } \\
\text { (A) }\end{array}$ & $\begin{array}{c}\text { زمان واكنش } \\
\text { (min) }\end{array}$ & 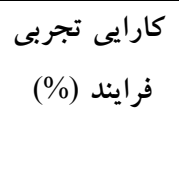 & فارايى تئوريكى \\
\hline 1 & $r$ & $\cdot 10$ & T/YO & 00 & זד & TV \\
\hline r & $\varepsilon$ & 1 & $1 / 0$ & v. & or & 09 \\
\hline$r$ & $r$ & $1 / 0$ & r/vo & 00 & vo & va \\
\hline$\varepsilon$ & r & 1 & $1 / 0$ & $\varepsilon$. & 00 & 09 \\
\hline 0 & $\varepsilon$ & $r$ & $1 / 0$ & $\varepsilon$. & $0 \wedge$ & 09 \\
\hline 7 & r & 1 & $1 / 0$ & v. & 70 & Tr \\
\hline V & $\varepsilon$ & 1 & $r$ & $\varepsilon$. & 07 & or \\
\hline$\wedge$ & $r$ & $1 / 0$ & T/YO & 10 & $V \varepsilon$ & vq \\
\hline 9 & $r$ & $1 / 0$ & T/YO & 00 & 71 & Tr \\
\hline 1. & r & $1 / 0$ & T/YO & or & 7. & $0 \wedge$ \\
\hline 11 & $r$ & $1 / 0$ & T/YO & 00 & 71 & זד \\
\hline Ir & $\varepsilon$ & r & $r$ & $\varepsilon$. & or & 7. \\
\hline $1 r$ & $\varepsilon$ & 1 & $1 / 0$ & $\varepsilon$. & $\varepsilon \wedge$ & 01 \\
\hline $1 \varepsilon$ & $r$ & $1 / 0$ & T/TO & To & $\varepsilon V$ & $\varepsilon V$ \\
\hline 10 & $r$ & $1 / 0$ & T/TO & 00 & זר & 70 \\
\hline 17 & $r$ & $1 / 0$ & - / Vo & 00 & 0. & or \\
\hline IV & $r$ & $r / 0$ & T/TO & 00 & TV & v. \\
\hline 11 & $r$ & $1 / 0$ & T/YO & 00 & 09 & $7 r$ \\
\hline 19 & r & r & $1 / 0$ & v. & $7 \varepsilon$ & 70 \\
\hline$r$. & r & 1 & $r$ & v. & $7 \varepsilon$ & TV \\
\hline YI & $r$ & $1 / 0$ & T/TO & 00 & $7 \pi$ & 70 \\
\hline Tr & 0 & $1 / 0$ & T/YO & 00 & oV & $0 \wedge$ \\
\hline r & $\varepsilon$ & $r$ & $1 / 0$ & V. & 71 & Tr \\
\hline$T \varepsilon$ & $r$ & $r$ & $1 / 0$ & $\varepsilon$. & $\varepsilon \varepsilon$ & \{\rceil \\
\hline ro & $\varepsilon$ & $r$ & $r$ & v. & $u$ & v. \\
\hline r & $r$ & $r$ & $r$ & v. & 70 & 77 \\
\hline TV & $r$ & 1 & $r$ & $\varepsilon$. & 0. & or \\
\hline$r \Lambda$ & 1 & $1 / 0$ & T/YO & 00 & $\varepsilon V$ & $\varepsilon \wedge$ \\
\hline$r q$ & r & $r$ & $r$ & $\varepsilon$. & $0 \wedge$ & $0 \wedge$ \\
\hline$r$. & $\varepsilon$ & 1 & $r$ & v. & r & TV \\
\hline
\end{tabular}


بهينهازى فرايند سونوالكترويرسولفات براى تصفيه شيرابه لندفيل با استفاده از مدل سطح یاسخ

جدول ع: نتايج آناليز واريانس براى مدل درجه دوم در فرايند سونو الكترويرسولفات در حذف COD

\begin{tabular}{|c|c|c|c|c|c|c|}
\hline SOURCE & SUM OF SQUARES & DF & MEAN SQUARE & F - VFEUE & $\begin{array}{l}\text { P-VFEUE } \\
\text { PROB > F }\end{array}$ & \\
\hline MODEL & 1354.78 & 14 & 96.77 & 4.53 & 0.0031 & significant \\
\hline $\mathrm{A}: \mathrm{PH}$ & 9.37 & 1 & 9.37 & 0.44 & 0.04177 & \\
\hline B: PS & 45.37 & 1 & 45.37 & 2.12 & 0.01656 & \\
\hline C: CURRENT & 260.04 & 1 & 260.04 & 12.17 & 0.0033 & \\
\hline D: TIME & 737.04 & 1 & 737.04 & 34.50 & $<0.0001$ & \\
\hline $\mathrm{AB}$ & 33.06 & 1 & 33.06 & 1.55 & 0.2326 & \\
\hline $\mathrm{AC}$ & 22.56 & 1 & 22.56 & 1.06 & 0.3204 & \\
\hline $\mathrm{AD}$ & 27.56 & 1 & 27.56 & 1.29 & 0.2738 & \\
\hline $\mathrm{BC}$ & 1.56 & 1 & 1.56 & 0.073 & 0.7905 & \\
\hline $\mathrm{BD}$ & 0.063 & 1 & 0.063 & $2.926 \mathrm{E}-003$ & 0.9576 & \\
\hline CD & 1.56 & 1 & 1.56 & 0.073 & 0.7905 & \\
\hline $\mathrm{A}^{\wedge} 2$ & 184.53 & 1 & 184.53 & 8.64 & 0.0032 & \\
\hline $\mathrm{B}^{\wedge} 2$ & 11.81 & 1 & 11.81 & 0.55 & 0.0014 & \\
\hline $\mathrm{C}^{\wedge} 2$ & 0.027 & 1 & 0.027 & $1.254 \mathrm{E}-003$ & 0.9722 & \\
\hline $\mathrm{D}^{\wedge} 2$ & 0.24 & 1 & 0.24 & 0.011 & 0.9168 & \\
\hline RESIDUFE & 320.42 & 15 & 21.36 & & & \\
\hline LACK OF FIT & 310.42 & 10 & 31.04 & 15.52 & 0.37 & Not significant \\
\hline PURE ERROR & 10.00 & 5 & 2.00 & & & \\
\hline COR TOTFE & 1675.20 & 29 & & & & \\
\hline
\end{tabular}

توافق منطقى با مقدار بارامتر مجذور مربعـات فواصـل تنظيم

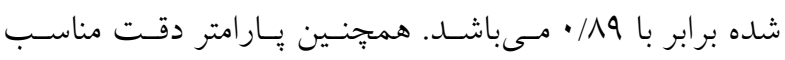
نشاندهنده نسـبت سـيخنال بـه نـويز (Adequate Precision)

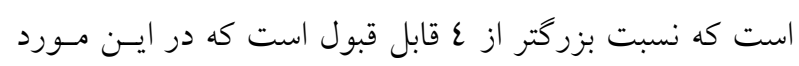

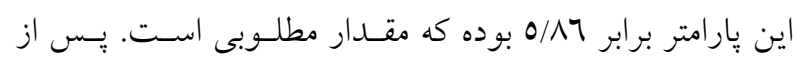

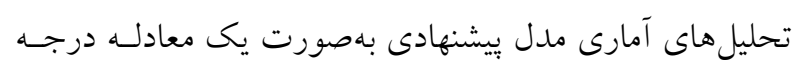

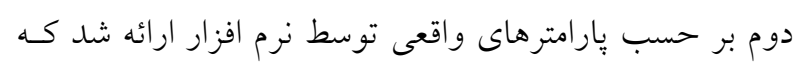
در رابطه ا نشان داده شده است. ايسن معادلـه رياضسى ميـزان

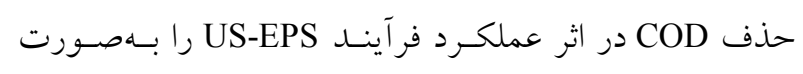

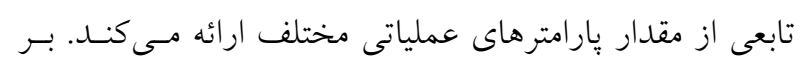

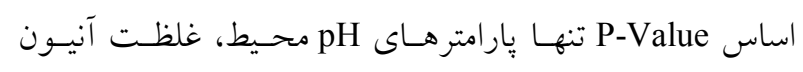

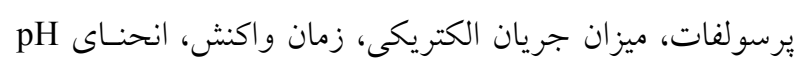

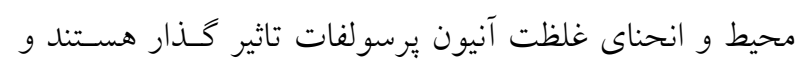

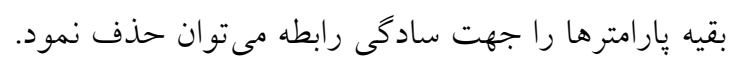
رابطه ): $\mathrm{R}_{1}=86.67+(5.12 \times \mathrm{A})+(5.21 \times \mathrm{B})+(3.96 \times \mathrm{C})+$ $(4.71 \times \mathrm{D})-(9.30 \times \mathrm{A} 2)-(5.05 \times \mathrm{B} 2)$

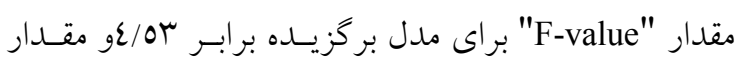
كوجهكتر از ه٪"P-value"

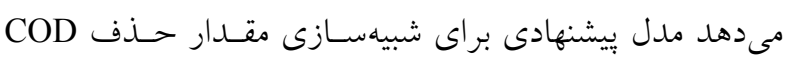

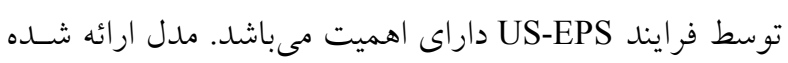

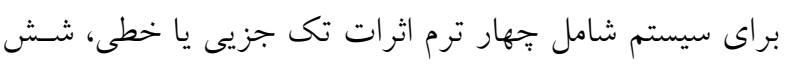

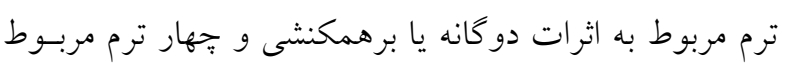

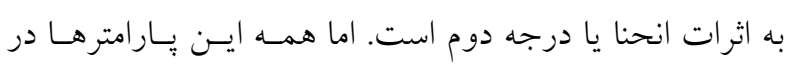

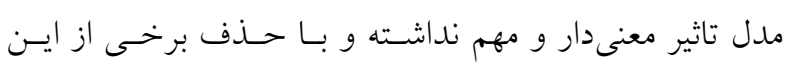

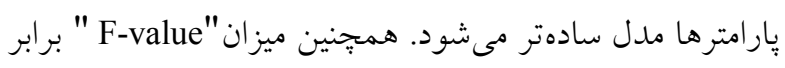

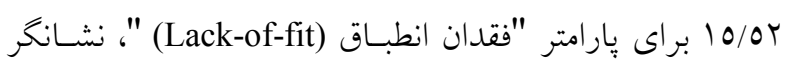

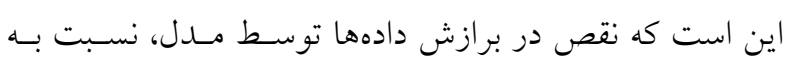

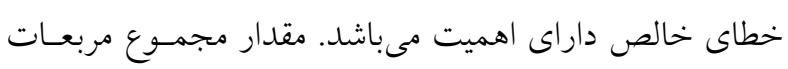

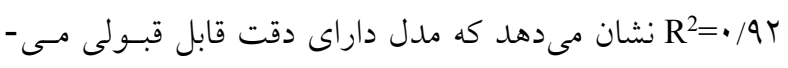

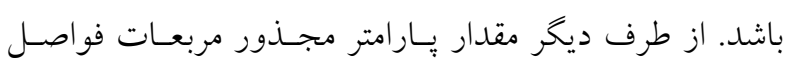

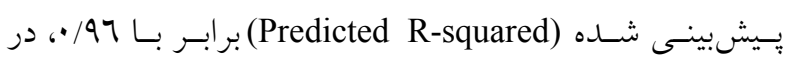


الكتريكى بارامترهاى انتخابى مقابـل هـم هسـتند كـه در ايسن

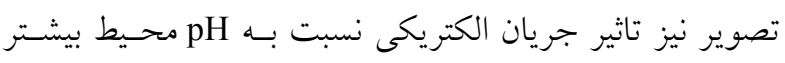

مى.باشد.

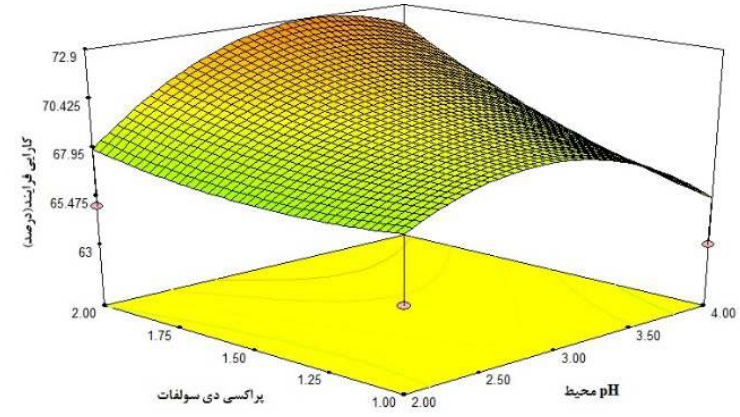

تصوير r: گراف سهبعدى مربوط به بازده حذف COD به عنسوان تـابعى از pH اوليهى محيط و غلظت آنيون برسولفات
نحوهى اثر متغيرها در فرآيند

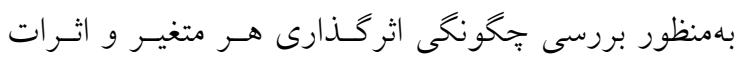

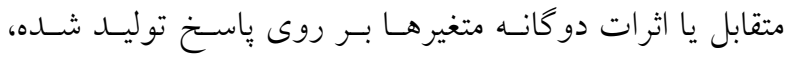
كرافهاى سهبعدى بر اساس تابع جند جملهاى تهيه كرديدند.

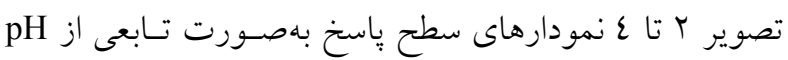

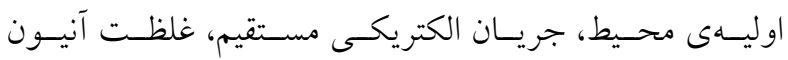

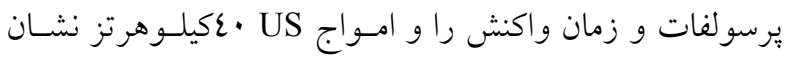
مى دهد. همانطور كه در تصوير Y مشاهده مى شودة، دو يارامتر

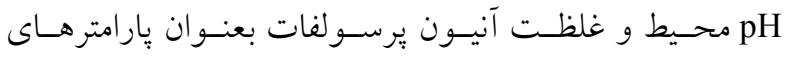

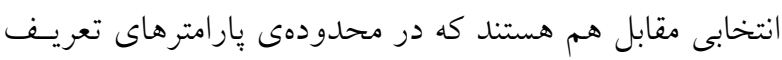

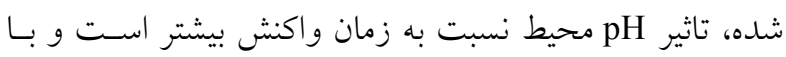
تغيير pH محيط فرايند بيشتر دستخوش تغييرات قرار مى گيــرد

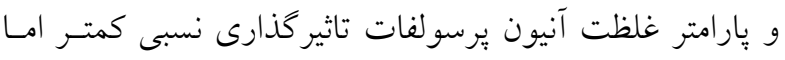
ييوسته نسبت به pH محيط دارد.

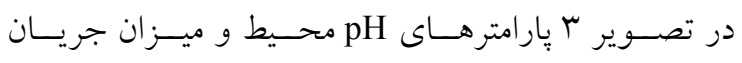

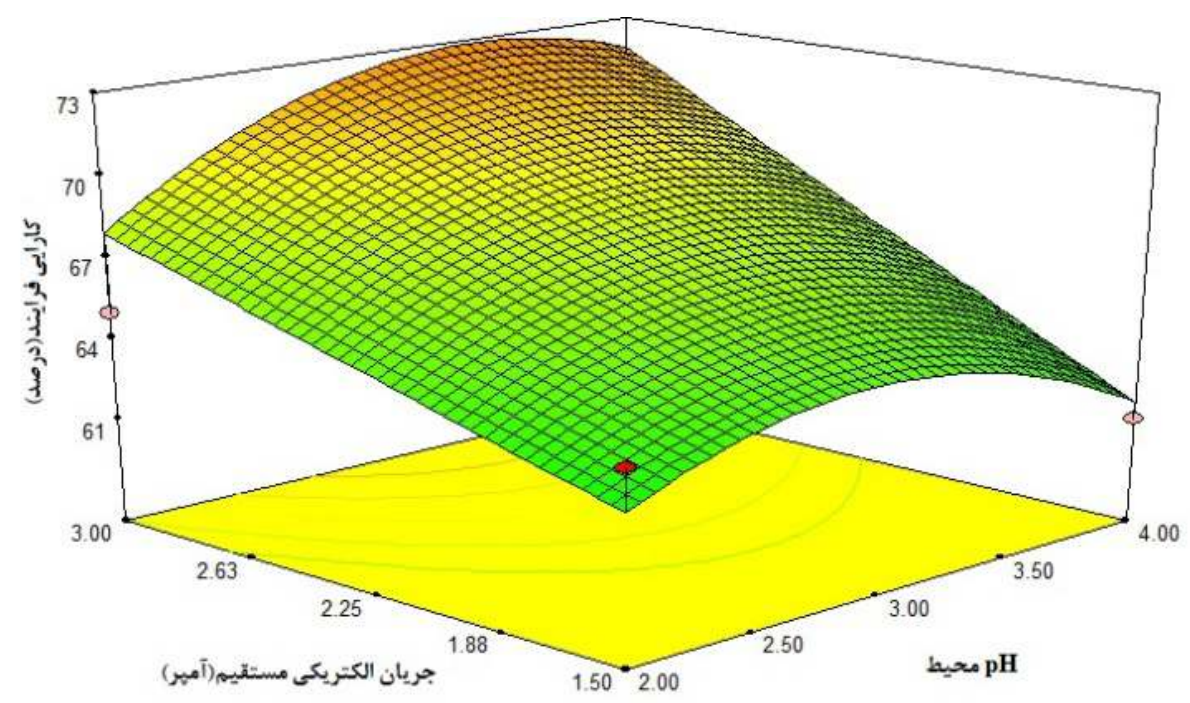

تصويرسّ: كراف سهبعدى مربوط به بازده حذف COD به عنوان تابعى از pH اوليهى محيط و ميزان جريان الكتريكى 
بهينهازى فرايند سونوالكترويرسولفات براى تصفيه شيرابه لندفيل با استفاده از مدل سطح پاسخ

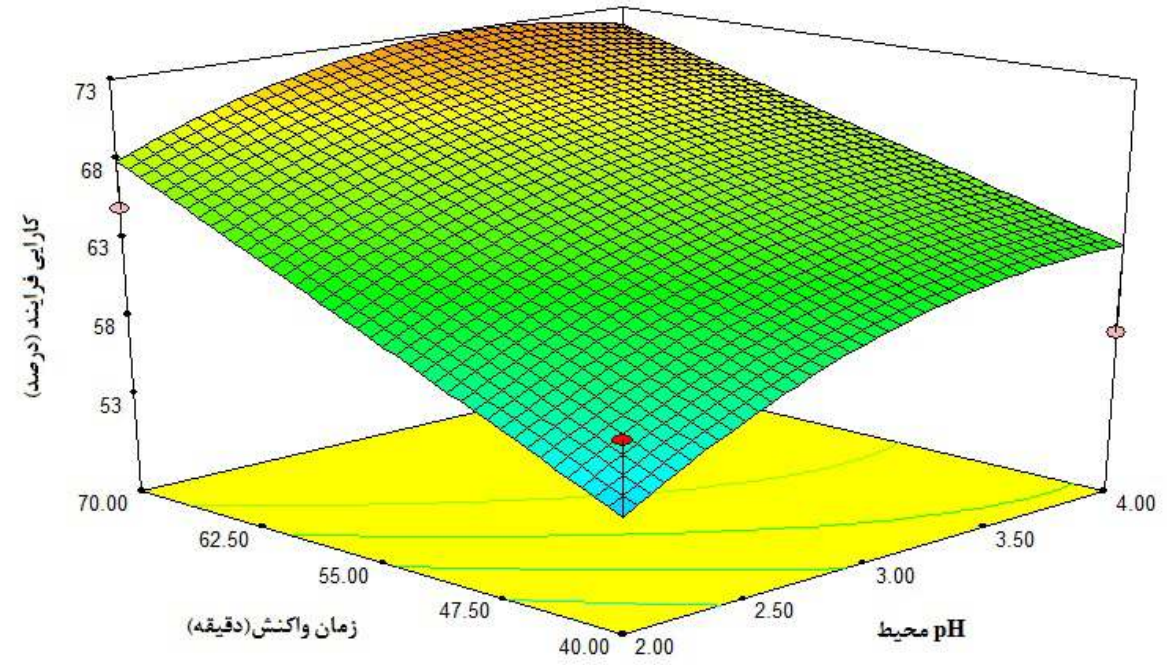

تصوير ع: گراف سهبعدى مربوط به بازده حذف COD به عنوان تابعى از pH محيط و زمان واكنش

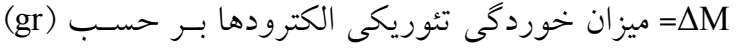

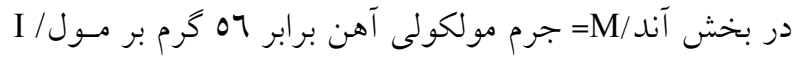

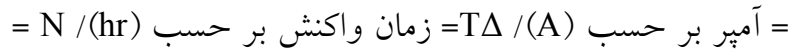

تعداد الكترودها در بخش آند/FNV ثابت فارادى برابر

بر اساس اين معادله در طول مدت زمان •V دقيقـه، ميـزان

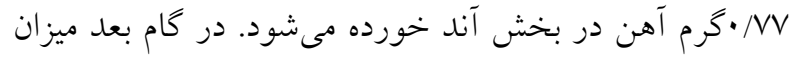

انرزى مصرفى در طول فرايند تخمين زده شـد. بـراى بدسـت

آوردن ميزان انرزى مصرفى از رابطهى ب استفاده شد '.

$\mathrm{UED}=(\mathrm{I} \times \mathrm{U} \times \mathrm{T}) /(1000 \times \mathrm{V} \times \mathrm{Co} \times \eta)$

رابطه

ميـزان انــرزى مصــــى (كيلــووات ســاعت بــر

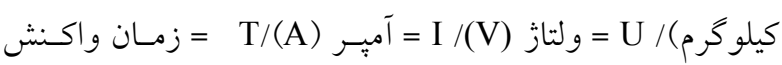

= Cل $\mathrm{C}_{0} /(\mathrm{hr})$

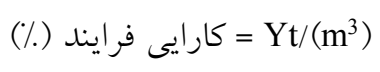

همتجنين به ازاى حمـام مـافوق صـوت / ب كيلـووات در

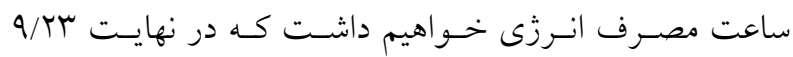

كيلووات بر ساعت بر كيلو گرم COD حذف شده تعيين شد. نتـايج تصـاوير SEM بهمــ SEAX و آنـاليز FT-IR در

$$
\text { تصاوير زير ارايه شده است. }
$$

در نمــودار ع، pH محــيط و زمــان واكــش، يارامترهــاى

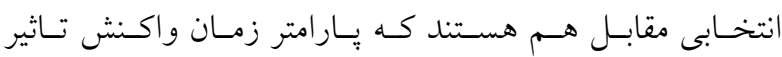
كذارترى نسبت به يار امتر pH محيط مىباشد.

\section{بينهسازى مدل}

بهينهسازى مدل و يافتن مقدار بهينه متغيرها بر اساس تـابع مطلوبيت توسط نرم افزار انجام شد. به اين منظور در نرم افزار شرايط بهينهسازى مربوط بـه هـر متغيـر و ياسـخهـا و ميـزان اهميت هر يك از آنها تعيين شد. همه يارامترها در رنج مربوط به طراحى تنظيم شدند. همجينين بازده تجزيه در مقدار مطلوب

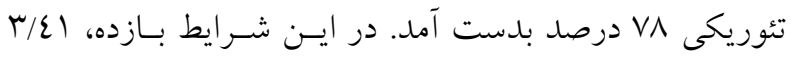
pH= جريان مستقيم الكتريكى برابر إع/2 آمير، غلظت آنيـون

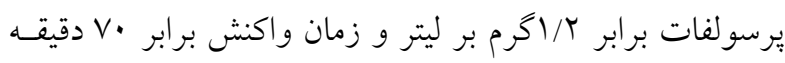
توسط مدل بيشبينى شد كـهـ بـازده تجربسى بـر اسـاس نتـايج آزمايشخاهى V0 درصد بدست آمد.

جهت تعيين ميزان خوردكى تئوريكى الكترودهـا از قـانون فارادى كه بصورت رابطهى r ارايه شده است بدست آمد ‘r. $\Delta \mathrm{M}_{\text {theo }}=(\mathrm{M} \times \mathrm{I} \times \Delta \mathrm{t}) /(\mathrm{N} \times \mathrm{F})$ رابطه 

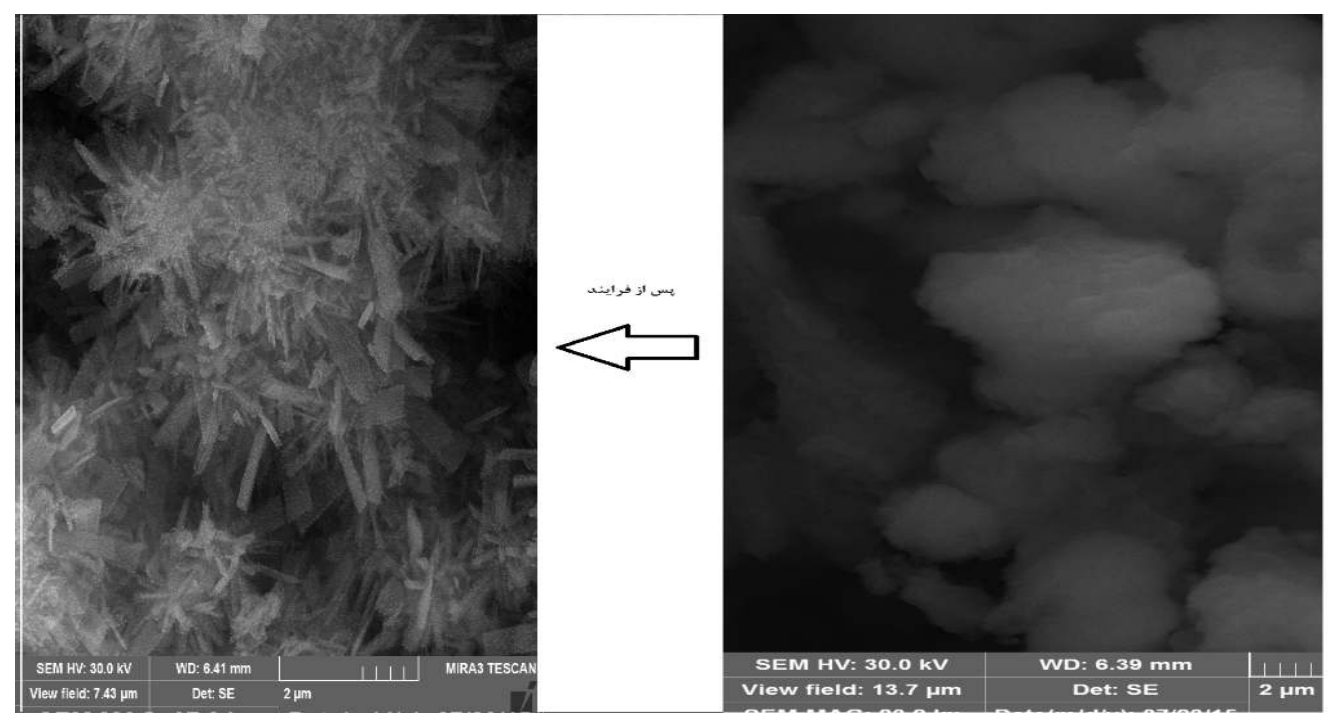

تصوير ه: نتايج مربوط به تصوير بردارى SEM و گراف مربوط به EDAX نمونه لجن قبل و بعد از فرايند

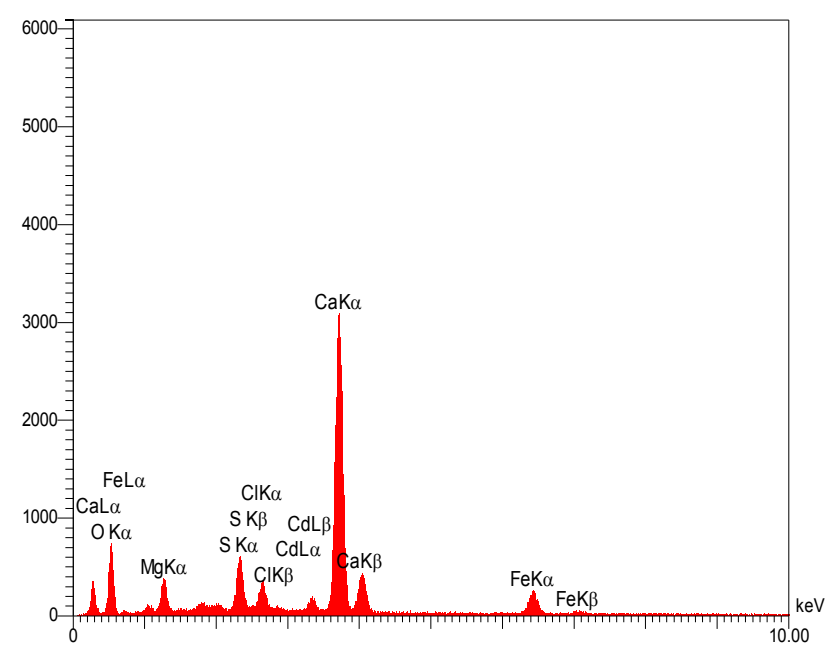

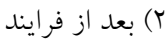

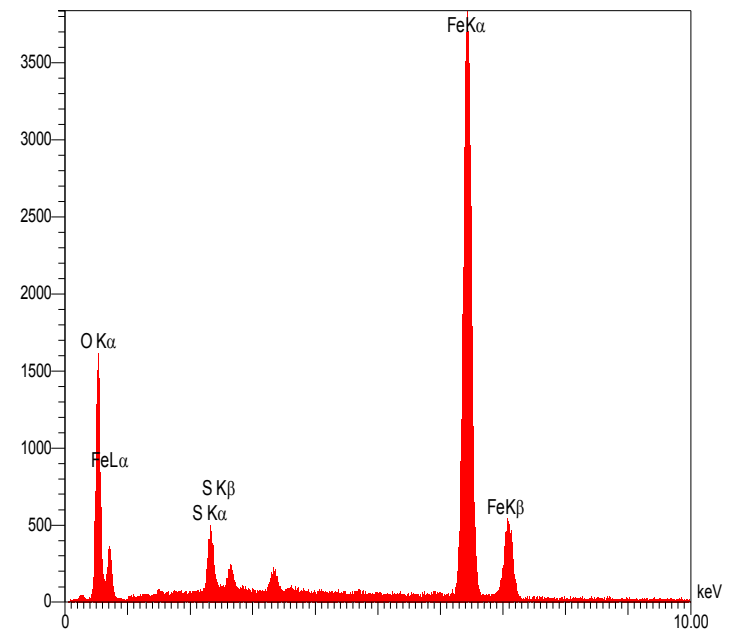

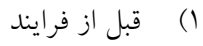

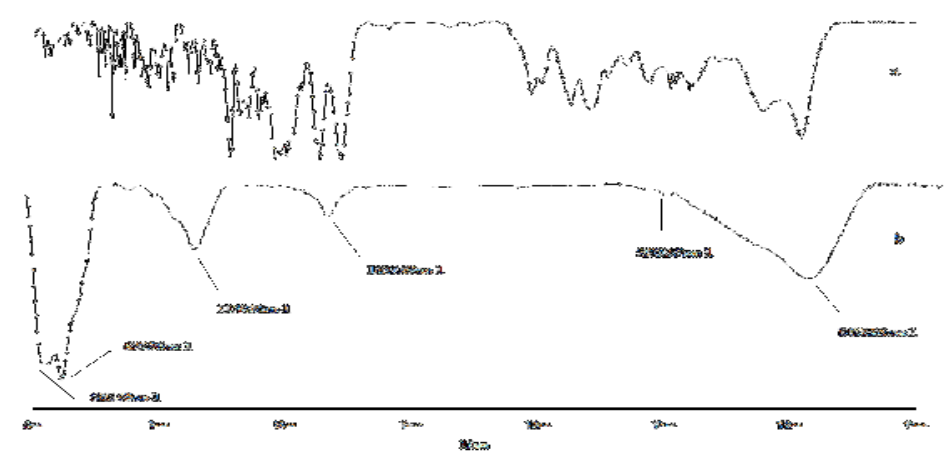

تصوير \&: نمودار FT-IR از نمونه لجن قبل و بعد از فرايند 
بنابر اين بهينه سازى بارامترهـا بـــر اسـاس ايـن جهـار پـارامتر

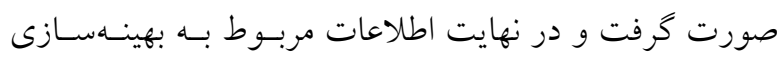

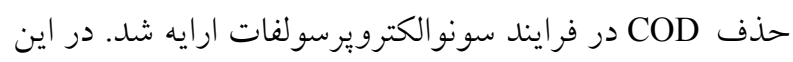

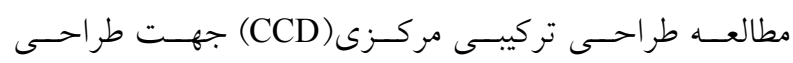

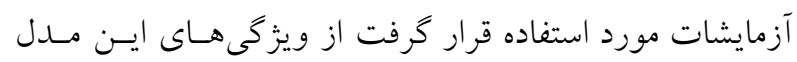

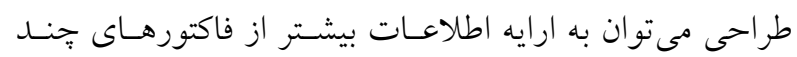

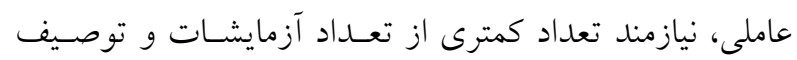

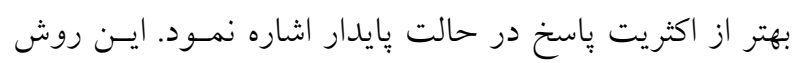

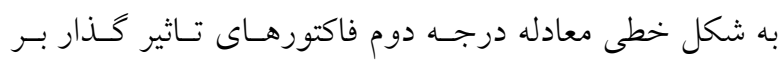

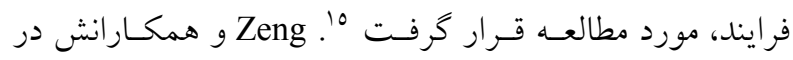

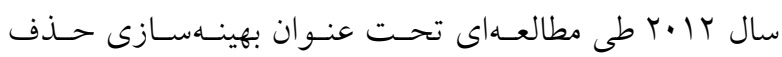

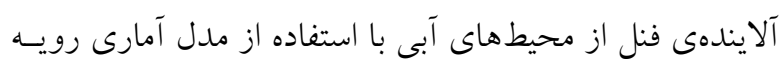

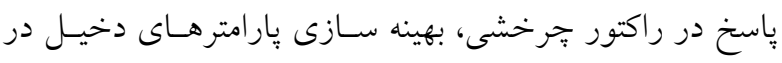

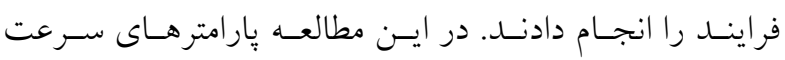

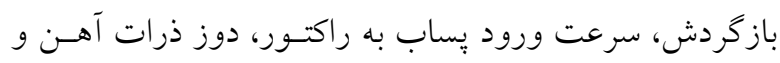

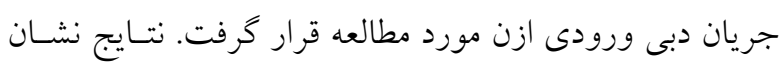

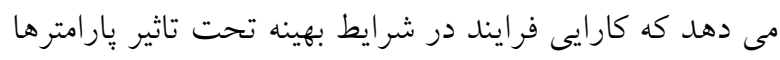

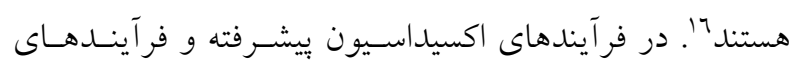

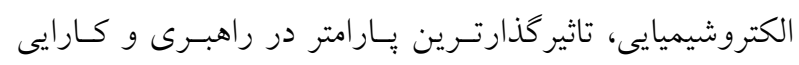

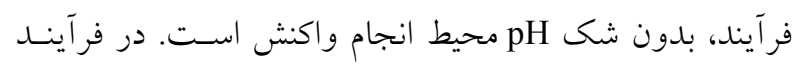

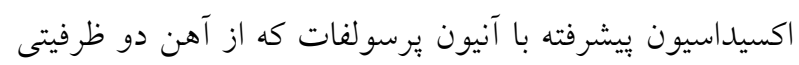

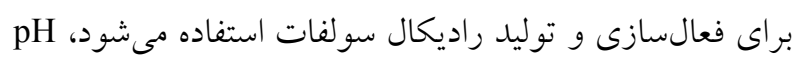

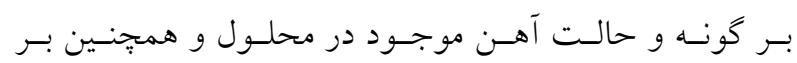

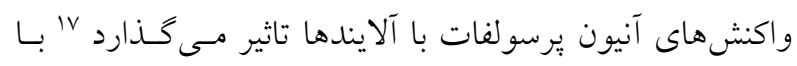

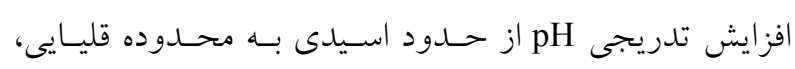

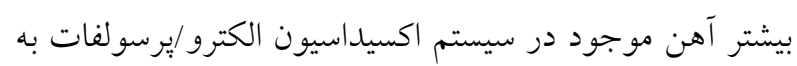

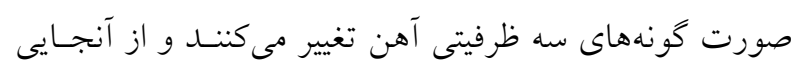

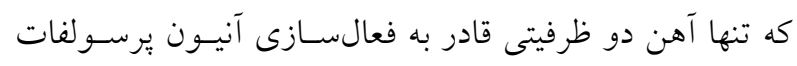

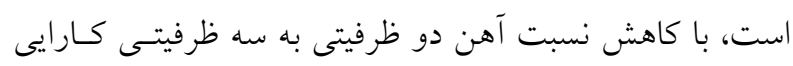

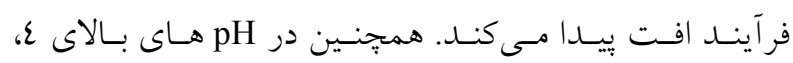

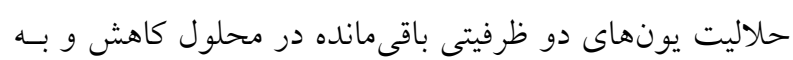

بحث بطور كلى فرايند US-EPS مىتوانــ تقريبـا ه V درصـد از COD دسـتخوش تـاثير يارامترهـاى pH محسيط، جريــان الكتريكـى مستقيم، زمان واكنش و غلظت آنيون برسولفات اسـت. ميـزان

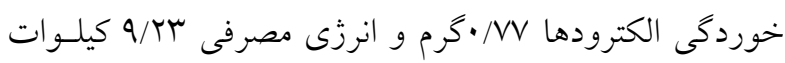
در ساعت به ازاى هـر كيلـو گرم COD اسـت. ميـزان ضـريب

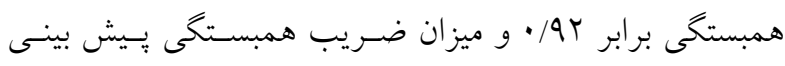

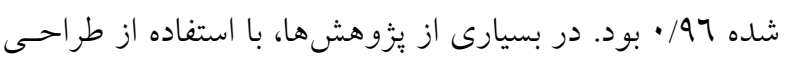
كالسـيك One Factor At Time) OFAT) ، يـك شـكاف در مطالعات به وجود مى آيـــ و آن عــدم تعيسين رابطـهـه و اثـرات متقابل متغيرهاى مورد بررسـى اسـت. جهــت بـر كـردن ايسن شكاف ازDOE DOE Design Of Expert) استفاده مىشـود. DOE مطالعه و بررسى توام تجندين متغير فرايند بطـورى كـه در هـر

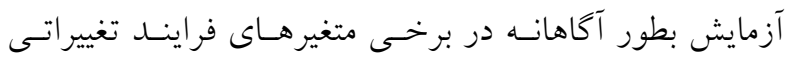
ايجاد مىشود و با تحليل ميزان تغييرات خروجى فرايند به اتـر

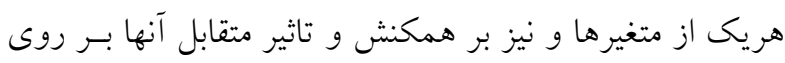

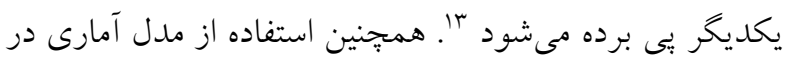
فرايندهاى تصفيه، روشى مناسب در راستاى جلو گيرى از بروز اشتباهات انسانى و به حداقل رساندن اين خطاها مسىباشـد. از ويزگ كى هاى برتر اين مدل آمارى مىتوان به كاهش بسيار زيـاد در تعداد نمونههاى آزمايشخاهى كه منجر به كاهش هزينه هاى

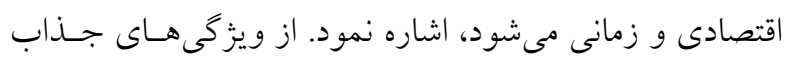

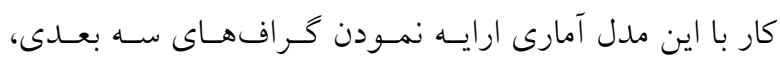

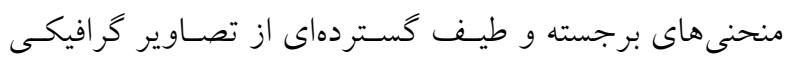

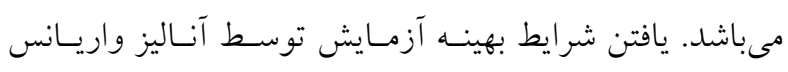

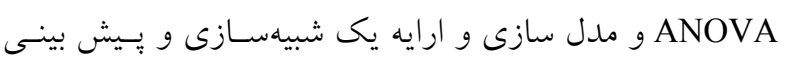

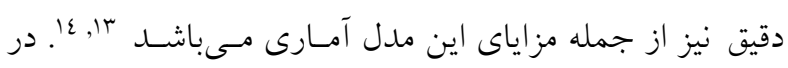

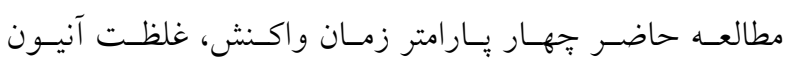
برسولفات، جريان الكتريكى مستقيم و pH اوليه محيط بعنـوان

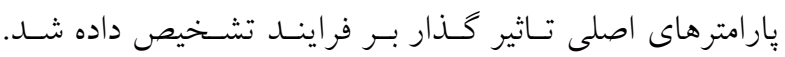




$$
\begin{aligned}
& \mathrm{S}_{2} \mathrm{O}_{8}{ }^{2-}+\mathrm{H}_{2} \mathrm{O} \rightarrow 2 \mathrm{HSO}_{4}^{-}+0.5 \mathrm{O}_{2} \quad \text { رابطهى } \\
& \mathrm{HSO}_{4}^{-} \rightarrow \mathrm{H}^{+}+\mathrm{SO}_{4}{ }^{2-}
\end{aligned}
$$

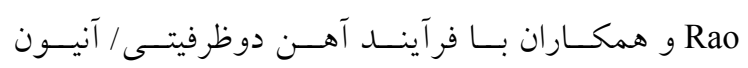

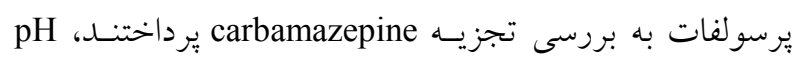

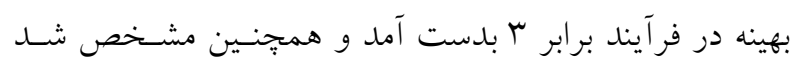

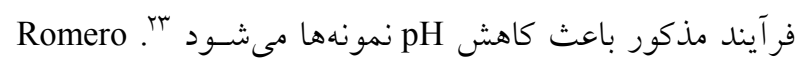

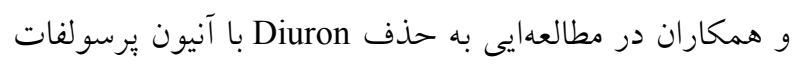

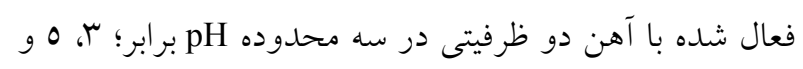

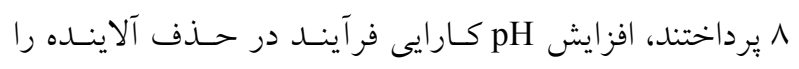
كاهش يافت عَب ميزان جريان الكتريكى مستقيم (آميراز) اعمال

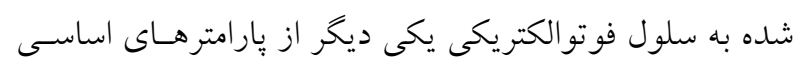

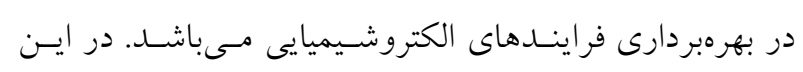

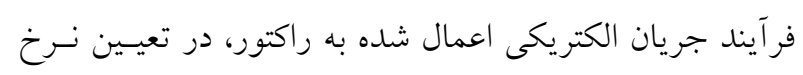

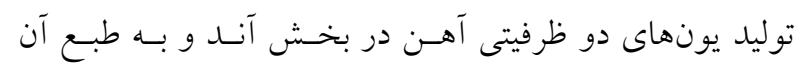

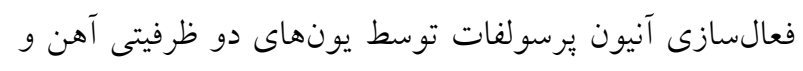

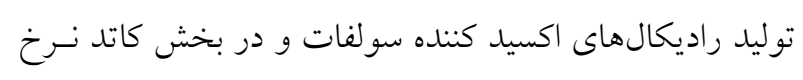

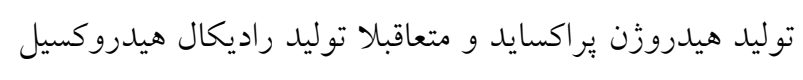

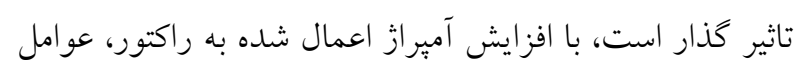

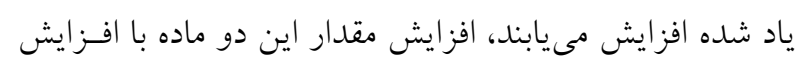

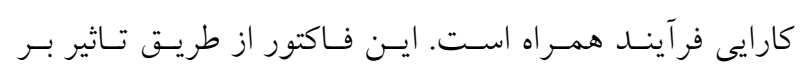

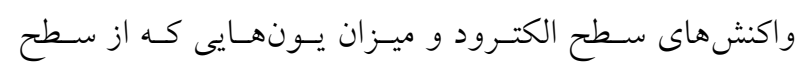

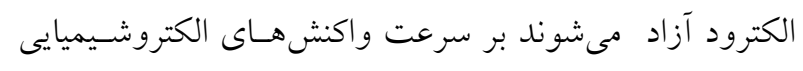

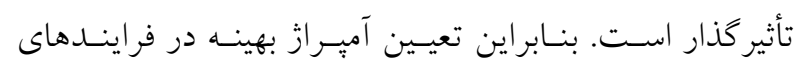
الكتريكى امرى ضرورى است. با افزايش آميراز جريان اعمـال

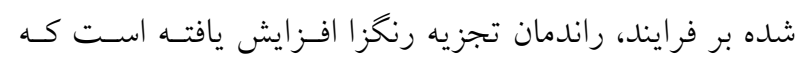

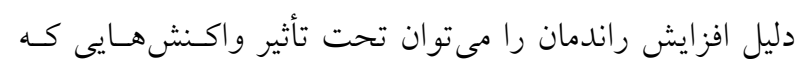

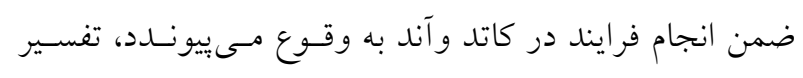

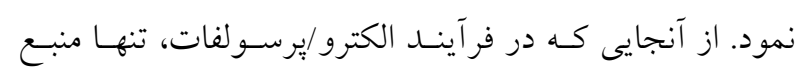

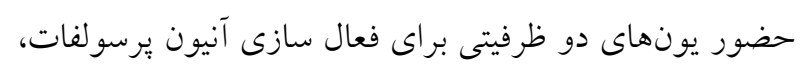

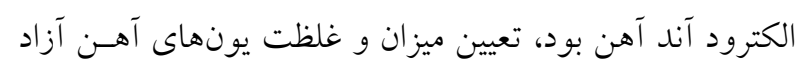

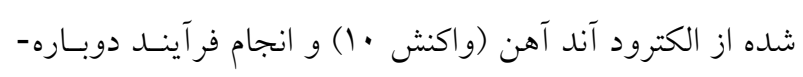

شكل كلوئيديى در مى آيد، اين بِديده نيز به نوبه خـود كـارايى را كاهش مى مهد (رابطهى ع) ".

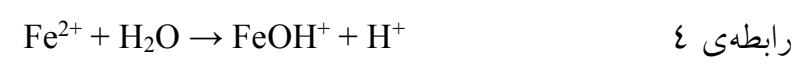
محصول فعالسازى آنيون يرسولفات با آهن دو ظرفيتى كه بـهـ

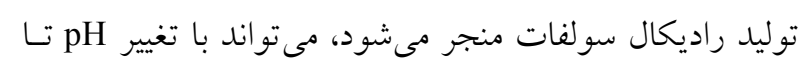

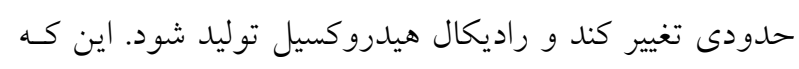

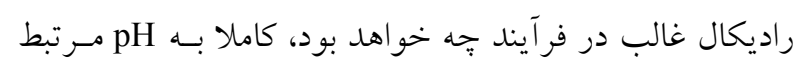

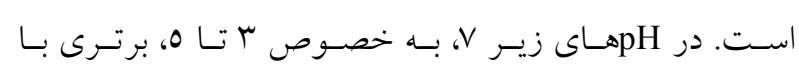

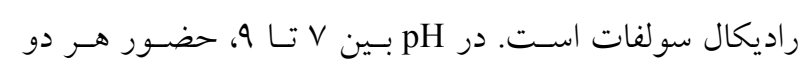
راديكال را مىتوان مشاهده كرد (رابطه 0) و در شرايط بسـيار

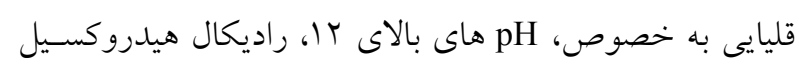

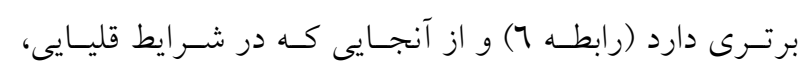

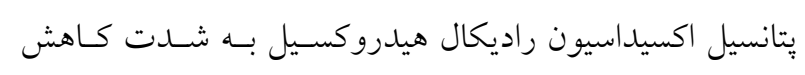
بيدا مى كند، كارايى فرآيند حتى در حضور غالب اين رادئ راديكـال

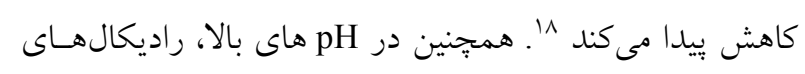

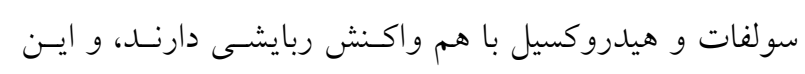

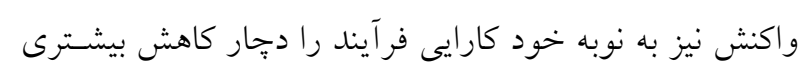

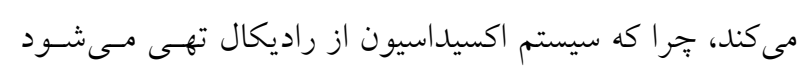
19 ( 19 (رابطه رابطهى 0 $\mathrm{SO}_{4}{ }^{--}+\mathrm{OH}^{-} \rightarrow \mathrm{OH}^{\bullet}+\mathrm{SO}_{4}^{2-}$ $\mathrm{SO}_{4}{ }^{--}+\mathrm{OH}^{\bullet} \rightarrow \mathrm{H}^{+}+\mathrm{SO}_{4}{ }^{2-}+0.5 \mathrm{O}_{2} \quad \mathrm{~V}$ رابطهى فعالسازى آنيون برسولفات با يونهاى دو ظرفيتى آهن كه

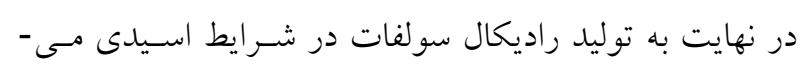
انجامد، مىتواند باعث كاهش بيشتر pH سيستم اكسيداسيون

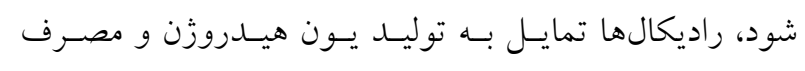

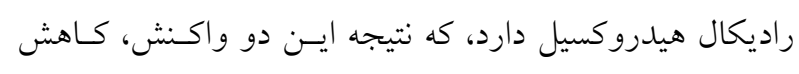

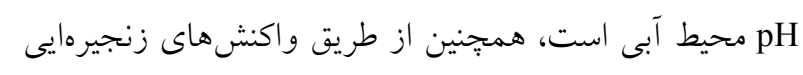

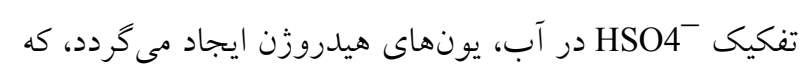

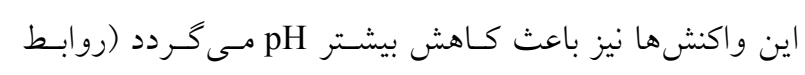

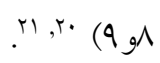




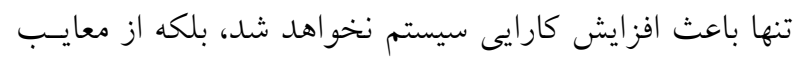

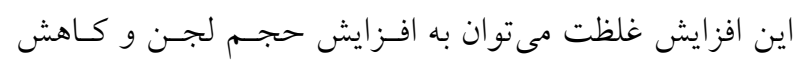

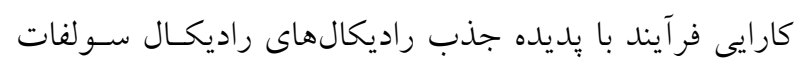

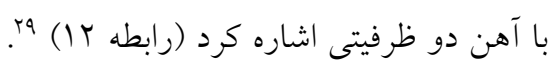
$\mathrm{SO}_{4}{ }^{--}+\mathrm{Fe}^{2+} \rightarrow \mathrm{SO}_{4}{ }^{2-}+\mathrm{Fe}^{3+} \quad$ رابطهى

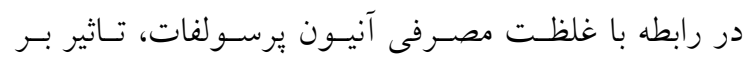

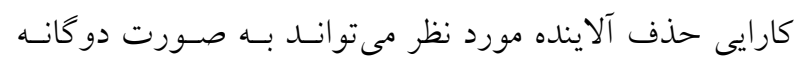
ظهور كند، افزايش غلظت اين ماده اكسيدان از حد خاصى، نـهـ

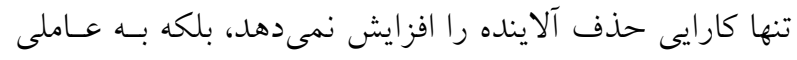
براى ربايش و مصرف راديكال هاى

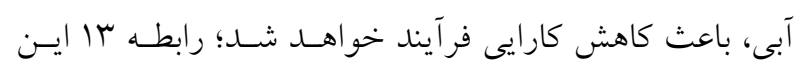

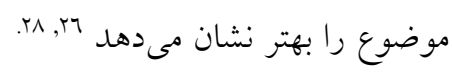
$\mathrm{S}_{2} \mathrm{O}_{8}{ }^{2-}+\mathrm{SO}_{4}{ }^{--} \rightarrow \mathrm{S}_{2} \mathrm{O}_{8}{ }^{--}+\mathrm{SO}_{4}{ }^{2-} \quad$ رابطهى

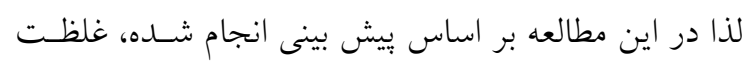

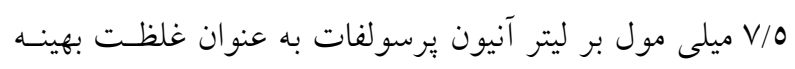

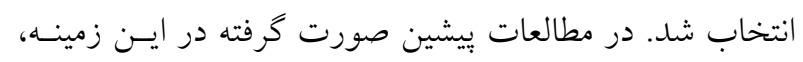

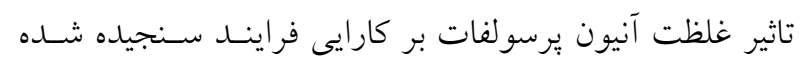

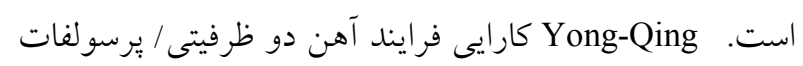
رادر حذف آنيلين را در غلظت يك ميلى مول بر ليتر بالاترين

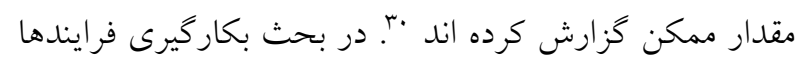

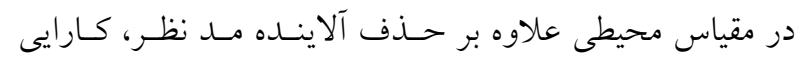

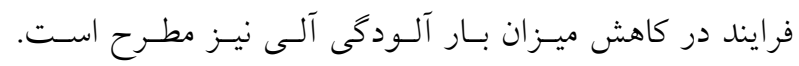

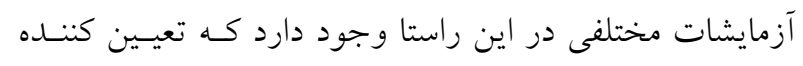

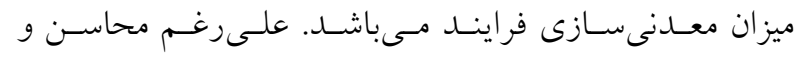

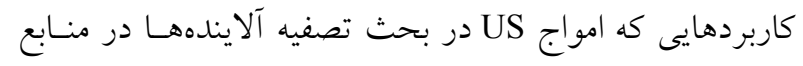

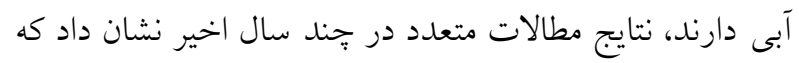

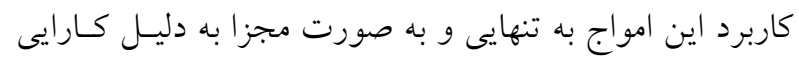

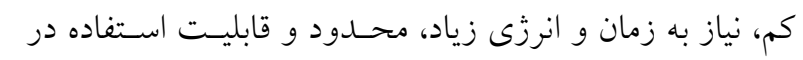

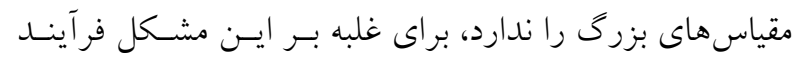

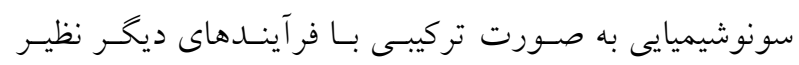

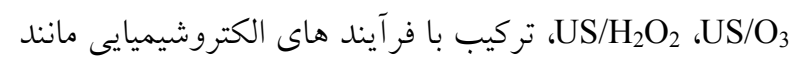

سازى يونهاى دو ظرفيتى از طريق احياء مداوم يونهـاى سـه

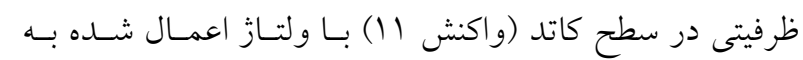

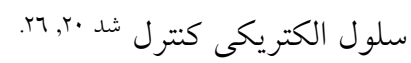

$\mathrm{Fe} \rightarrow \mathrm{Fe}^{2+}+2 \mathrm{e}^{-}$ رابطهى 1. $\mathrm{Fe}^{3+}+\mathrm{e}^{-} \rightarrow \mathrm{Fe}^{2+}$ رابطهى 11

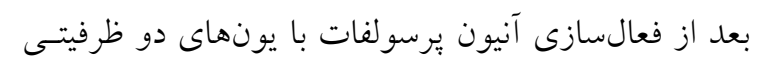

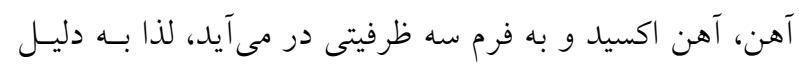

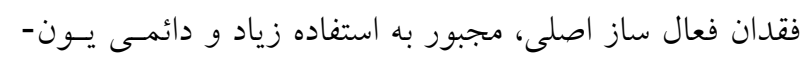

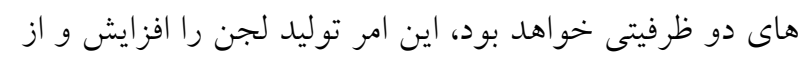

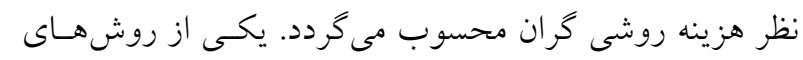

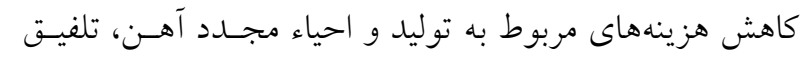

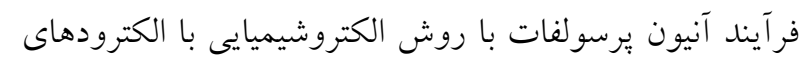

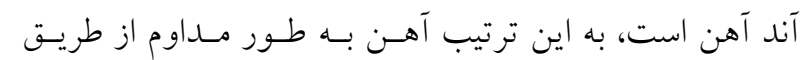

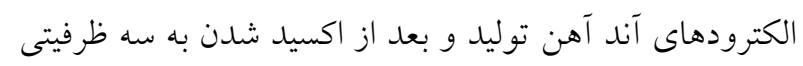

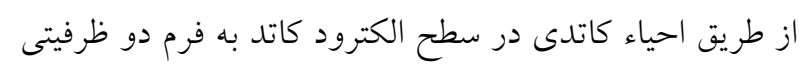

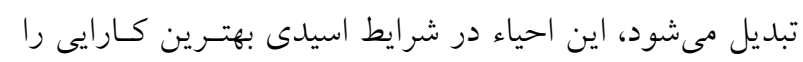

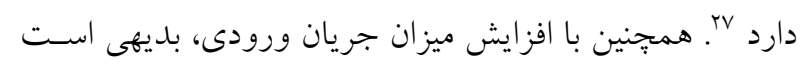

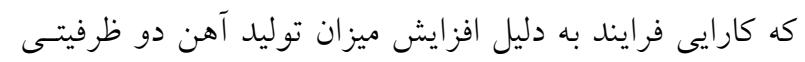

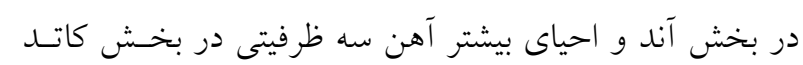

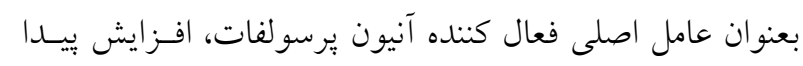

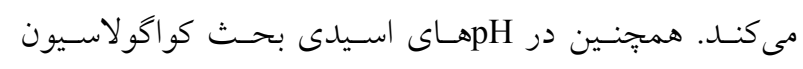
آلاينده توسط فرايند الكتروكواگولاسيون به دليل حضور كونه -

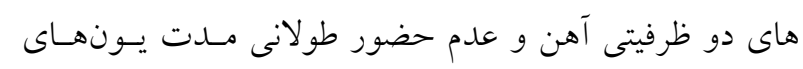

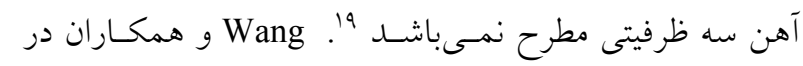

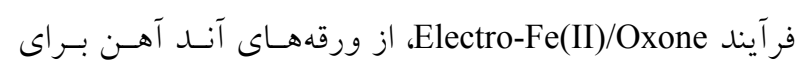

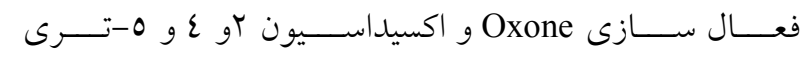
كلروفنوكسى استيك استفاده كرداند، هر يـك مـول از تركيـبـ قادر به توليد ب مول از Oxone

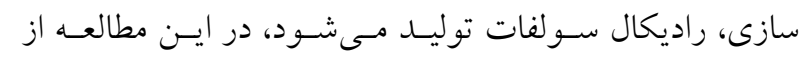

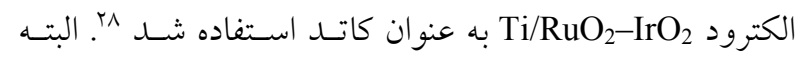
افزايش غلظت يونهاى دو ظرفيتى آهن از مقادير مشخص نـــ 
امواج US همجنين قـادر اسـت، آهـن مـورد نيـاز فر آينـد الكتروفنتون و الكترويرسولفات را بعد از تبديل بـهـ يـونهـاى با سرعت بيشترى به يونهـاى Fe $\mathrm{Fe}^{3+}$ $r^{r 7}(1 /$

$\left.\left.\left.\mathrm{Fe}^{3+}+\mathrm{e}^{-}+\right)\right)\right) \rightarrow \mathrm{Fe}^{2+}$ رابطه 11

طيف سنجى مادون قرمز بر اساس جذب تابش و بررسى جهشهاى ارتعاشى مولكولها و يونهاى جند اتمسى صـورت مى كيرد. اين روش بـه عنوان روشى يرقـدرت و توسـعه يافتـهـ براى تعيين ساختار و اندازه كيرى گونه هاى شيميايى به كار مى رود. همجنين اين روش عمدتاً براى شناسايى تركيبات آلى بـهـ

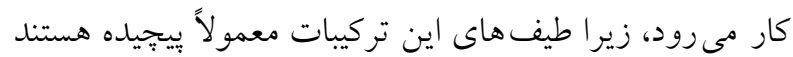
و تعلداد زيادى بيكى هاى ماكسيمم و مينيمم دارند كه مى توانند FT-IR براى اهداف مقايسه ايى به كار كرفته شوند. نتايج آناليز (قسمت a تصـويره) بيـانكر حضـور بيـك و دره بسـيارى در تركيب لجن خشك شده قبل فرايند مىباشد كه هريك نشانگر كروههاى عاملى خاص مى باشد. بس از انجـام فراينـد، نتـايج

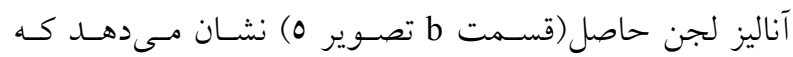
بسيارى از اين تركيبات در طى فرايند از بــين رفتـهانـد و تنهـا جند گروه عاملى مانند آلدييدها(

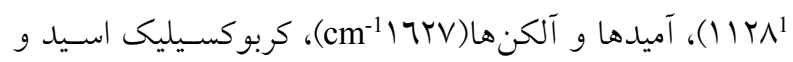
آلكانها (

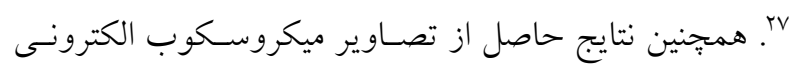
روبشى نشان مىدهد كه ساختار ابر مانند شيرابه قبل از فراينـد به حالت لخته هاى سر سوزنى با نوك هاى براق تبـديل شـده است كه نشان دهنده حضور اهن در اين نقاط است. همجنـين نتايج نمودار EDAX نشان دهنده تغييـر در سـاختار عنصسرى نمونه لجن حاصل از فرايند سونوالكترويرسولفات است. بدين شكل كه عناصر آهن و اكسيزن در نمونه بشدت افـزايش بيــا كرده اند. بر همين اساس برخى فرايندهاى نوين كه در راستاى تصفيه شيرابه انجام كرفته است جهت مقايسـه بــا ايسن فراينــ

$$
\text { ارايه شده است (جدوله). }
$$

US/Electro Fenton فرآيندهاى نورى و فوتوكاتاليستى، انجام مسىشـود با. حضـور امواج US از جندين جهت، خاصيت همافزايى بر فراينـد دارد. ابتدا به ساكن، حضور US به تنهايى بـا ايجـاد اسـترس باعـث تخريب حلقهها و بيوندهاى موجود در تركيبات آلى مى شـود. از سوى ديخـــ در حضـور مولكـول آب و اكسـيزن، بـه دليـل فروياشى ميكروحبابهاى حاصل از كاويتاسيون باعـث ايجـاد نقاط موضعى يرفشار و حرارتى مىشود كه باعث تسريع توليد

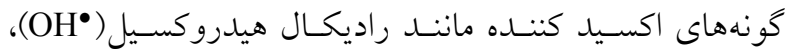

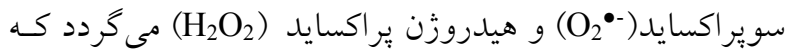
در نهايت منتج به انجام اكسيداسيون آندى مىشـود. همجنــين امواج US باعث تسهيل در كنده شدن يونهاى تجمع يافته بـر سطح الكترودها و تاثير بر جلو گيرى از افت جريان الكتريكى و افزايش قطبيت الكتريكى در محفظه واكنش خواهـد داشـت r' دو مكانيسم عمــه مسـئول تخريسب آلاينـدههـا در خـلال سونوليز عبارتند از واكنش بيروليز در حبابهاى كاويتاسـيون، واكنشهـاى راديكـالى توسـط راديكـالهــاى هيدروكسـيل و هيدروزن شكل كرفته از طريق سونوليز آب ايسن دو مكانيسـم ريسم

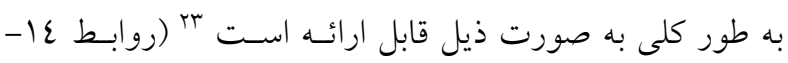

$R-\stackrel{\Delta+)))}{\rightarrow}$ Pyrolysis $\operatorname{Pr}$ oduct

رابطه ع

$\mathrm{H}_{2} \mathrm{O}-\stackrel{\Delta+()))}{\rightarrow} \mathrm{H}^{\circ}+\mathrm{HO}^{\circ}$

رابطه 10

$H O^{\circ}+R \stackrel{\Delta+)))}{\longrightarrow} \operatorname{Pr}$ oduct رابطه 17

عامل ديخر كـهـ بــراى افـزايش كـارايى فراينــ در حضـور امواج US مىتوان اشاره نمود اين موضوع اسـت كـه يكى از راهكارهاى فعال سـازى آنيـون برسـولفات و توليــ راديكـال

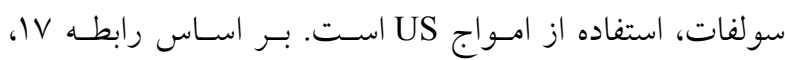
حضور امواج US مى تواند باعث توليد راديكال سولفات شود ro, r乏 $\left.\left.\left.\mathrm{S}_{2} \mathrm{O}_{8}^{2-+}\right)\right)\right) \rightarrow 2 \mathrm{SO}_{4}^{\bullet-}$

رابطه 
بهينهسازى فرايند سونوالكترويرسولفات براى تصفيه شيرابه لندفيل با استفاده از مدل سطح پاسخ

جدوله: مقايسه برخى فرايندهاى تصفيه شيرابه

\begin{tabular}{|c|c|c|c|}
\hline رفرنس & درصد كارايى & نويسنده & عنوان \\
\hline$r \Lambda$ & 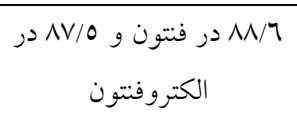 & Gandhimathi & $\begin{array}{l}\text { Stabilized landfill leachate treatment using heterogeneous Fenton and } \\
\text { electro-Fenton processes }\end{array}$ \\
\hline rq & va & Wang & $\begin{array}{l}\text { Insights into sludge granulation during anaerobic treatment of high- } \\
\text { strength leachate via a full-scale IC reactor with external circulation system }\end{array}$ \\
\hline \multirow[t]{4}{*}{ r. } & & Gogate & $\begin{array}{l}\text { Treatment of landfill leachate using different configurations of ultrasonic } \\
\text { reactors combined with advanced oxidation processes }\end{array}$ \\
\hline & $\mathrm{US}+\mathrm{O} 3=r \varepsilon / 0$ & & \\
\hline & $\mathrm{US}+\mathrm{H} 2 \mathrm{O} 2=\varepsilon r$ & & \\
\hline & $\mathrm{US} /$ Fenton $=\mathrm{V} r$ & & \\
\hline$\mu_{1}$ & $7 \cdot-0$. & Spagni & $\begin{array}{c}\text { Assessment of dynamic membrane filtration for biological treatment of old } \\
\text { landfill leachate }\end{array}$ \\
\hline rr & $\wedge r$ & Oumar Dia & $\begin{array}{c}\text { Hybrid process, electrocoagulation-biofiltration for landfill leachate } \\
\text { treatment }\end{array}$ \\
\hline
\end{tabular}

اندك بعنوان فرايندى يـاك و دوسـتلدار محسيط شـناخته شــده

تتيجه خيرى

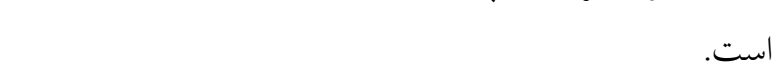

$$
\begin{aligned}
& \text { تشكر و قدردانى }
\end{aligned}
$$

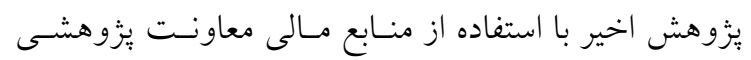

$$
\begin{aligned}
& \text { دانشخاه علوم يزشكى همدان تحت عنوان طرح تحقيقـاتى بـهـ } \\
& \text { انجام رسيده است كه نويسندگان مقاله از همكارى آن معاونت } \\
& \text { كمال تشكر را دارند. }
\end{aligned}
$$

\section{References}

1. Słomczyńska B, Słomczyński T. Physico-chemical and toxicological characteristics of leachates from MSW landfills. Pol J Environ Stud 2004;13:627-37.

2. Panizza M, Delucchi M, Sirés I. Electrochemical process for the treatment of landfill leachate. J Appl Electrochem 2010;40(10):1721-7.

3. Silveira JE, Zazo JA, Pliego G, Bidóia ED, Moraes PB. Electrochemical oxidation of landfill leachate in a flow reactor: optimization using response surface methodology. Environ Sci Pollut Res 2014:1-11.

4. Amor C, De Torres-Socías E, Peres JA, Maldonado MI, Oller I, Malato S, et al. Mature landfill leachate treatment

$$
\begin{aligned}
& \text { نتايج ارايه شده در اين مطالعه بيانخر اين موضوع مى باشد }
\end{aligned}
$$

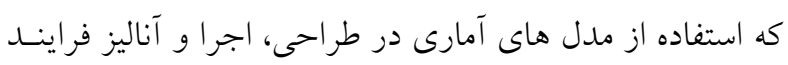

$$
\begin{aligned}
& \text { داراى نتايج بسيار مطلوب مى باشد و بهرهذيرى از ايسن روش } \\
& \text { باعث كاهش خطاهاى انسانى و دســاهى در تمـامى سـطوح } \\
& \text { مى گردد. همجنين نتايج ارايه شده مشخص نمـود كـه كـارايى } \\
& \text { فراينــد سـونو الكترويرسـولفات در حسـف COD حساصـل از } \\
& \text { شيرابه بسيار مناسب است و مىتوان با استفاده از اين روش، با } \\
& \text { كارايى بالايى آلايندها را حذف نمود. اين فرايند با توليد لجن }
\end{aligned}
$$

by coagulation/flocculation combined with Fenton and solar photo-Fenton processes. J Hazard Mater 2014.

5. Lutze HV, Bakkour R, Kerlin N, von Sonntag C, Schmidt TC. Formation of bromate in sulfate radical based oxidation: Mechanistic aspects and suppression by dissolved organic matter. Water Res 2014;53:370-7.

6. Samarghandi M, Shabanlo A, Mehralipour J. Efficiency of Electro/Persulfate (EPS) Process in Degrading High Concentrations of Ceftriaxone in Pharmaceutical Effluents.Water Wastewater J 2016;27(4):15-25. [In Persian]

7. Lin H, Zhang H, Hou L. Degradation of CI Acid Orange 7 in aqueous solution by a novel electro/ $\mathrm{Fe}_{3} \mathrm{O}_{4} / \mathrm{PDS}$ 


$$
\text { مجيد كرمانى و همكاران }
$$

process. J Hazard Mater. 2014;276:182-91.

8. Rahmani A, Mehralipor J, Shabanloo N, Zaheri F, Poreshgh Y, Shabanloo A. Performance Evaluation of Advanced Electrochemical Oxidation Process With the Using Persulfate in Degradation of Acid Blue 113 from Aqueous Solutions. Jondi Shapour Univ Med Sci 1970;21(5):797-807. [In Persian]

9. Samarghandi M, Mehralipour J, Azarin G, Godini K, Shabanlo A. Decomposition of sodium dodecylbenzene sulfonate surfactant by electro/ $\mathrm{Fe}^{2+}$-activated persulfate process from aqueous solutions. Global Nest J 2017;19(1):115-21.

10. Samarghandi MR, Leili M, Godini K, Mehralipour J, Harati R. Furfural removal from synthetic wastewater by persulfate anion activated with electrical current: energy consumption and operating costs optimization. Der Pharma Chemica 2015;7(7):48-57.

11. Li Y, Hsieh W-P, Mahmudov R, Wei X, Huang C. Combined ultrasound and Fenton (US-Fenton) process for the treatment of ammunition wastewater. J Hazard Mater 2012;224:403-411.

12. Ioan I, Wilson S, Lundanes E, Neculai A. Comparison of Fenton and sono-Fenton bisphenol A degradation. J Hazard Mater 2007;142(1):559-63.

13. Cai C, Zhang H, Zhong X, Hou L. Electrochemical enhanced heterogeneous activation of peroxydisulfate by $\mathrm{Fe}-\mathrm{Co} / \mathrm{SBA}-15$ catalyst for the degradation of Orange II in water. Water Res 2014;66:473-85.

14. Moghaddam SK, Rasoulifard M, Vahedpour M, Eskandarian M. Removal of tylosin from aqueous solution by UV/nano $\mathrm{Ag} / \mathrm{S} 2 \mathrm{O} 82$ - process: Influence of operational parameters and kinetic study. Korean J Chem Eng 2014:1-5.

15. Singh B, Chakkal SK, Ahuja N. Formulation and optimization of controlled release mucoadhesive tablets of atenolol using response surface methodology. AAPS Pharm Sci Tech 2006;7(1):E19-E28.

16. Azevedo AN, Buarque PR, Cruz EMO, Blank AF, Alves $\mathrm{PB}$, Nunes ML, et al. Response surface methodology for optimisation of edible chitosan coating formulations incorporating essential oil against several foodborne pathogenic bacteria. Food Control 2014;43:1-9.

17. Wang X, Wang L, Li J, Qiu J, Cai C, Zhang H. Degradation of Acid Orange 7 by persulfate activated with zero valent iron in the presence of ultrasonic irradiation. Sep Purif Technol 2013;122:41-6.

18. Li G, Wong K, Zhang $\mathrm{X}$, Hu C, Yu JC, Chan R, et al. Degradation of Acid Orange 7 using magnetic $\mathrm{AgBr}$ under visible light: the roles of oxidizing species. Chemosphere 2009;76(9):1185-91.

19. Moreira FC, Soler J, Fonseca A, Saraiva I, Boaventura RA, Brillas E, et al. Electrochemical advanced oxidation processes for sanitary landfill leachate remediation: Evaluation of operational variables. Appl Catal B Environ
2016;182:161-71.

20. Xu H-y, Yang Z-h, Zeng G-m, Luo Y-l, Huang J, Wang $\mathrm{L}-\mathrm{k}$, et al. Investigation of $\mathrm{pH}$ evolution with $\mathrm{Cr}$ (VI) removal in electrocoagulation process: Proposing a realtime control strategy. Chem Eng J 2014;239:132-40.

21. Li Y, Hsieh W-P, Mahmudov R, Wei X, Huang C. Combined ultrasound and Fenton (US-Fenton) process for the treatment of ammunition wastewater. J Hazard Mater 2012;244-245:403-11.

22. Kovatcheva VK, Parlapanski MD. Sonoelectrocoagulation of iron hydroxides. Colloids and Surfaces A 1999;149(1):603-8.

23. Lakshmi PM, Sivashanmugam P. Treatment of oil tanning effluent by electrocoagulation: Influence of ultrasound and hybrid electrode on COD removal. Sep Purif Technol 2013;116:378-84.

24. Li J, Song C, Su Y, Long H, Huang T, Yeabah TO, et al. A study on influential factors of high-phosphorus wastewater treated by electrocoagulation-ultrasound. Environ Sci Pollut Res 2013;20(8):5397-404.

25. Hou L, Zhang H, Xue X. Ultrasound enhanced heterogeneous activation of peroxydisulfate by magnetite catalyst for the degradation of tetracycline in water. Sep Purif Technol 2012;84:147-52.

26. Pang YL, Abdullah AZ, Bhatia S. Review on sonochemical methods in the presence of catalysts and chemical additives for treatment of organic pollutants in wastewater. Desalination 2011;277(1):1-14.

27. Ahmed MG, Harish N, Charyulu RN, Prabhu P. Formulation of chitosan-based ciprofloxacin and diclofenac film for periodontitis therapy. Trop J Pharm Res 2009;8(1):33-41.

28. Sruthi T, Gandhimathi R, Ramesh S, Nidheesh P. Stabilized landfill leachate treatment using heterogeneous Fenton and electro-Fenton processes. Chemosphere 2018;210:38-43.

29. Wang T, Huang Z, Ruan W, Zhao M, Shao Y, Miao H. Insights into sludge granulation during anaerobic treatment of high-strength leachate via a full-scale IC reactor with external circulation system. J Environ Sci 2018;64:227-34.

30. Joshi SM, Gogate PR. Treatment of landfill leachate using different configurations of ultrasonic reactors combined with advanced oxidation processes. Sep Purif Technol 2019;211:10-8.

31. Saleem M, Spagni A, Alibardi L, Bertucco A, Lavagnolo MC. Assessment of dynamic membrane filtration for biological treatment of old landfill leachate. J Environ Manage 2018;213:27-35.

32. Dia O, Drogui P, Buelna G, Dubé R. Hybrid process, electrocoagulation-biofiltration for landfill leachate treatment. Waste Manage 2018;75:391-9. 